\title{
Nucleation and growth of sub-3 $\mathrm{nm}$ particles in the polluted urban atmosphere of a megacity in China
}

\author{
Huan Yu ${ }^{1,2,3}$, Luyu Zhou ${ }^{1}$, Liang Dai ${ }^{1}$, Wenchao Shen ${ }^{1}$, Wei Dai ${ }^{1}$, Jun Zheng ${ }^{1,2,3}$, Yan Ma ${ }^{1,2,3}$, and Mindong Chen ${ }^{1,2,3}$ \\ ${ }^{1}$ School of Environmental Science and Engineering, Nanjing University of Information Science \\ and Technology, Nanjing, China \\ ${ }^{2}$ Collaborative Innovation Center of Atmospheric Environment and Equipment Technology, \\ Nanjing University of Information Science and Technology, Nanjing, China \\ ${ }^{3}$ Jiangsu Key Laboratory of Atmospheric Environment Monitoring and Pollution Control, Nanjing, China
}

Correspondence to: Huan Yu (hyu@nuist.edu.cn)

Received: 22 June 2015 - Published in Atmos. Chem. Phys. Discuss.: 9 July 2015

Revised: 15 February 2016 - Accepted: 22 February 2016 - Published: 3 March 2016

\begin{abstract}
Particle size distribution down to $1.4 \mathrm{~nm}$ was measured in the urban atmosphere of Nanjing, China, in spring, summer, and winter during 2014-2015. Sub-3 nm particle event, which is equivalent to nucleation event, occurred on 42 out of total 90 observation days, but new particles could grow to cloud condensation nuclei $(\mathrm{CCN})$-active sizes on only 9 days. In summer, infrequent nucleation was limited by both unfavorable meteorological conditions (high temperature and relative humidity - RH) and reduced anthropogenic precursor availability due to strict emission control measures during the 2014 Youth Olympic Games in Nanjing. The limiting factors for nucleation in winter and spring were meteorological conditions (radiation, temperature, and $\mathrm{RH}$ ) and condensation sink, but for the further growth of sub$3 \mathrm{~nm}$ particles to $\mathrm{CCN}$-active sizes, anthropogenic precursors again became limiting factors. Nucleation events were strong in the polluted urban atmosphere. Initial $J_{1.4}$ at the onset and peak $J_{1.4}$ at the noontime could be up to $2.1 \times 10^{2}$ and $2.5 \times 10^{3} \mathrm{~cm}^{-3} \mathrm{~s}^{-1}$, respectively, during the eight nucleation events selected from different seasons. Time-dependent $J_{1.4}$ usually showed good linear correlations with a sulfuric acid proxy for every single event $\left(R^{2}=0.56-0.86\right.$, excluding a day with significant nocturnal nucleation), but the correlation among all eight events deteriorated $\left(R^{2}=0.17\right)$ due to temperature or season change. We observed that new particle growth rate (GR) did not increase monotonically with particle size, but had a local maximum up to $25 \mathrm{~nm} \mathrm{~h}^{-1}$ between 1 and $3 \mathrm{~nm}$. The existence of local maxima GR in sub$3 \mathrm{~nm}$ size range, though sensitive to measurement uncertain-
\end{abstract}

ties, gives new insight into cluster dynamics in polluted environments. In this study such growth rate behavior was interpreted as the solvation effect of organic activating vapor in newly formed inorganic nuclei.

\section{Introduction}

New particle formation (NPF) is an important source of secondary aerosols in the atmosphere (Kulmala et al., 2004a). Field studies and model simulations have consistently shown that NPF can enhance cloud condensation nuclei $(\mathrm{CCN})$ concentrations and contribute significantly to the global $\mathrm{CCN}$ production (Wiedensohler et al., 2009; Yue et al., 2011; Spracklen et al., 2008; Pierce and Adams, 2009; Merikanto et al., 2009; Yu and Luo, 2009; Matsui et al., 2013). NPF is a two-stage process consisting of the formation of clusters and subsequent growth to detectable sizes (Kulmala et al., 2000). Recently, chamber experiments have made substantial progress in revealing the fundamental processes involved in particle nucleation and growth (Kirkby et al., 2011; Almeida et al., 2013; Schobesberger et al., 2013; Riccobono et al., 2014; Ehn et al., 2014; Kürten et al., 2014). However, consistent theories are still under investigation to quantify the processes physically, chemically, and dynamically (Kulmala et al., 2013, 2014). For example, the identity and physico-chemical properties of assisting vapors other than sulfuric acid $\left(\mathrm{H}_{2} \mathrm{SO}_{4}\right)$ are uncertain so far. It is also uncertain what mechanisms allow for the assisting vapors to over- 
come strong Kelvin effect over sub-3 nm particles. Existing mechanisms include condensation of extremely low volatility organic compounds (Ehn et al., 2014), nano-Köhler activation (Kulmala et al., 2004b), heterogeneous chemical reactions (Zhang and Wexler, 2002), heterogeneous nucleation (Wang et al., 2013), and adsorption of organics on cluster surface (Wang and Wexler, 2013). However, the relative importance of various mechanisms is unknown.

Direct measurements of size- and time-dependent nucleation rate and growth rate in sub- $3 \mathrm{~nm}$ size range are important to constrain the relative contributions from different mechanisms and precursors. Such measurements are also important to evaluate the survival probability of new particle to $\mathrm{CCN}$-active sizes $(\sim 100 \mathrm{~nm}$ for soluble particles at $0.2 \%$ super saturation; Pierce and Adams, 2009) and to reveal the limiting factors in the process. Recently, a series of new instruments have been developed to measure sub$3 \mathrm{~nm}$ aerosol number concentration and chemical composition, such as condensation particle counters (e.g., PSM, DEG-SMPS, Jiang et al., 2011a; Sipila et al., 2009; Vanhanen et al., 2011), ion spectrometers (e.g., NAIS, Asmi et al., 2009), and mass spectrometers (e.g., Cluster-CIMS, APiTOF, CI-APi-TOF (chemical ionization atmospheric pressure interface time-of-flight) mass spectrometer, Jokinen et al., 2012; Junninen et al., 2010; Zhao et al., 2010). Kuang et al. (2012) developed a de-coupling method to measure sizeand time-dependent growth rates of sub- $5 \mathrm{~nm}$ particles. Their results at two urban sites in USA showed that size-resolved growth rates increased approximately linearly with particle size from 1 to $5 \mathrm{~nm}$. Similar results were also observed in the boreal forest (Kulmala et al., 2013; Lehtipalo et al., 2014). Based on growth rates measured below $2 \mathrm{~nm}$, Kulmala et al. (2013) identified three separate size regimes, which were dominated by different key gas to particle conversion processes.

The relative contribution of different precursors and mechanisms to the nucleation and growth of $1-3 \mathrm{~nm}$ particles may vary greatly with atmospheric conditions (Riipinen et al., 2012). Therefore, sub-3 $\mathrm{nm}$ particle measurements in a variety of atmospheric conditions, e.g., remote or urban atmosphere, biogenic, or anthropogenic emission-dominated areas, are immensely valuable. Unfortunately, such data are very sparse until now (Jiang et al., 2011b; Kuang et al., 2012; Kulmala et al., 2013; Lehtipalo et al., 2009, 2010, 2011; Yu et al., 2014a, b). China has suffered from severe atmospheric particulate matter pollution in recent years (Chan and Yao, 2008; Yue et al., 2011). To the best of our knowledge, only two studies were conducted in China to measure the occurrence of new particles down to $\sim 1 \mathrm{~nm}$. In these two studies, air ions (Herrmann et al., 2014) or neutral particles (Xiao et al., 2015) were measured by air ion spectrometer (AIS) or particle size magnifier (PSM) in two urban locations of Yangtze River Delta (YRD) region. Both studies were conducted in the winter season.
Here we reported the nucleation and growth of sub- $3 \mathrm{~nm}$ particles in the urban atmosphere of Nanjing, China on arbitrarily selected observation days in the spring, summer, and winter of 2014-2015. Our aim was to (1) provide new information about the initial steps of NPF based on size- and time-resolved nucleation rate and growth rate measurements, and (2) find possible limiting factors behind the seasonal and diurnal variations of nucleation events in the polluted urban atmosphere.

\section{Methodology}

\subsection{Field measurements}

Nanjing is the second largest megacity after Shanghai in the YRD region of China (Chan and Yao, 2008). The YRD city cluster, covering $2.1 \times 10^{5} \mathrm{~km}^{2}$ land with 170 million residents, is one of the most populated and industrialized regions in China. Field measurement was conducted from the third floor (15 $\mathrm{m}$ above the ground level) of an academic building beside a Chinese national meteorology observatory facility on the Nanjing University of Information Science and Technology (NUIST) campus $\left(32.20^{\circ} \mathrm{N}, 118.71^{\circ} \mathrm{E}\right.$; symbol (1) in Fig. 1). The sampling was carried out during the months of May (10-30 20 May14), June (1-15 June 2014), December (24-31 December 2014), February (16-22 February 2015), and March (1-7 March 2015). A total of 58 measurement days were arbitrarily selected to represent spring, early summer, and winter seasons, but to avoid any rain event.

As part of an intensive summer campaign (12 August12 September 2014), the summer measurement was conducted at a local governmental meteorology observatory platform $\left(32.06^{\circ} \mathrm{N}, 118.70^{\circ} \mathrm{E}\right)$ that is $14 \mathrm{~km}$ south of the NUIST site ((2) in Fig. 1). The instruments were housed in an airconditioned trailer, using exactly the same sampling inlets as the NUIST site. The main aim of the summer campaign was to understand the effects of regional emission control measures during the 2014 Young Olympic Games (1 August15 September) on air quality. Since the two sites were located within the same urban air shed, the measurement provided an opportunity to study seasonal variation of nucleation and its relationship with meteorological variables and gaseous precursors.

Sub-3 nm clusters/particles (hereafter referred as particles) were measured with a nano-condensation nucleus counter system (nCNC) consisting of a particle size magnifier (PSM; model A10, Airmodus Oy, Finland) and a butanol condensation particle counter (model A20, Airmodus Oy, Finland). During the measurement, an ambient airflow of 14 standard liters per minute (standard $\mathrm{L} \mathrm{min}^{-1}$ ) was drawn into building room or trailer via a $72 \mathrm{~cm}$ long and $1.0 \mathrm{~cm}$ I.D. diameter stainless steel (SS) tube, which was extended outside the room/trailer horizontally. PSM then sampled a split flow of 2.5 standard $\mathrm{L} \mathrm{min}^{-1}$ via a SS T-union. The design of the in- 


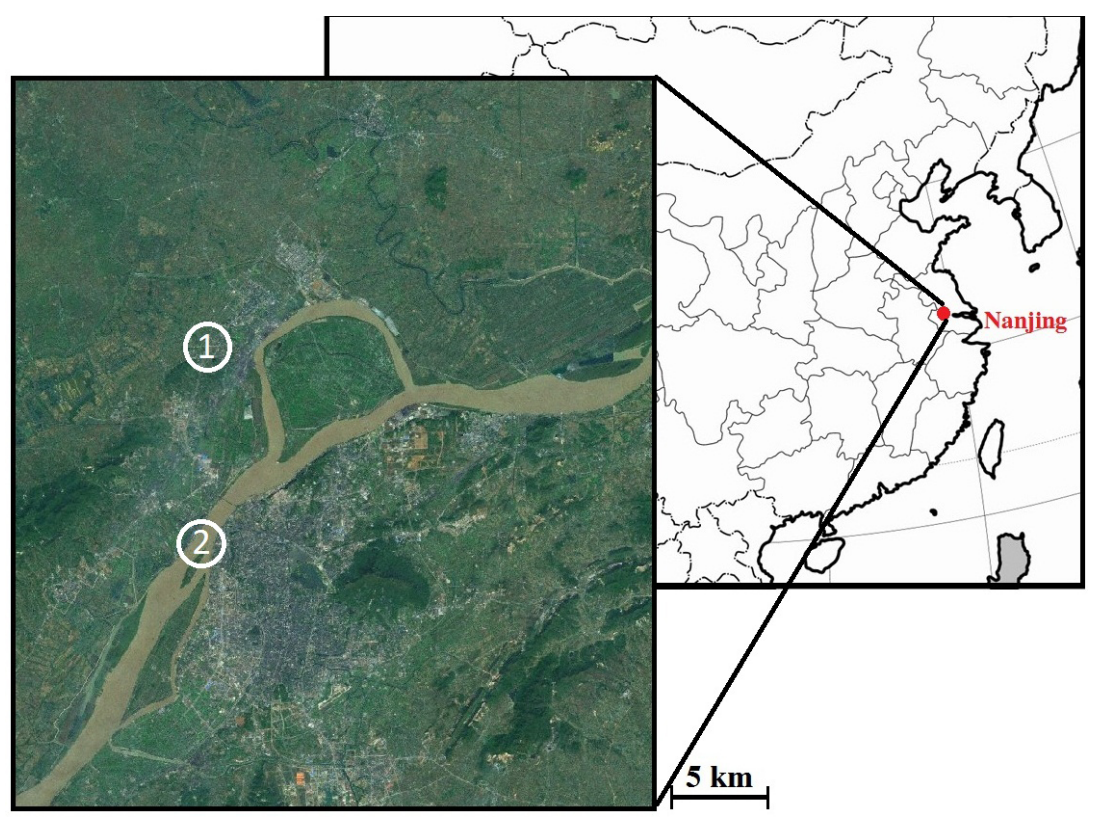

Figure 1. Locations of two urban measurement sites in Nanjing, the second largest megacity in the Yangtze River Delta region, China, (1) are the NUIST site and (2) is the summer measurement site.

let tubing (length and airflow rate) was to minimize the transport loss of nano-particles. The size-dependent transport survival ratios of sub- $3 \mathrm{~nm}$ particles in the inlet tubing were estimated (67-86\% for 1.4-3.0 nm) and corrected using a particle loss calculator tool (von der Weiden et al., 2009).

PSM was operated in a continuous scanning mode with a cycle of 240 steps between saturator flow rates of 0.1 and 1.0 standard $\mathrm{L} \mathrm{min}^{-1}$ within $240 \mathrm{~s}$. The particle cutoff sizes of the nCNC varied with saturation ratios in the saturator (Vanhanen et al., 2011). A stepwise method was used to invert raw scanning data to size spectrum (time resolution: $4 \mathrm{~min}$ ) of sub-3 $\mathrm{nm}$ particles, which were classified evenly into 6 size bins, i.e. 1.4-1.6, 1.6-1.9, 1.9-2.2, 2.2$2.4,2.4-2.7$, and $2.7-3.0 \mathrm{~nm}$. The particle number concentrations were then smoothed with a moving average filter for minimizing the effect of noises and fluctuations. The inverted particle number concentrations in the 6 bins were referred as $N_{1.5}, N_{1.8}, N_{2.0}, N_{2.3}, N_{2.6}$, and $N_{2.8}$, using mean values of upper and lower size boundaries in each bin. The stepwise method was described in detail by Lehtipalo et al. (2014).

Particle size distributions in the range from 3 to $750 \mathrm{~nm}$ were obtained by integrating two scanning mobility particle spectrometers (SMPS) with a nano-SMPS (a TSI differential mobility analyzer DMA3085 and a condensation particle counter CPC 3776 ; scanning range: $3-64 \mathrm{~nm}$ ) and a long SMPS (TSI DMA3081 and CPC3775; scanning range: 64$750 \mathrm{~nm}$ ). During the summer campaign, only the long-SMPS was operated to scan particles from 8 to $350 \mathrm{~nm}$. Scanning cycles of both SMPS systems were $4 \mathrm{~min}$, in order to synchronize with the nCNC. The SMPSs sampled ambient air from a separate sampling inlet. The inlet was a $129 \mathrm{~cm}$ long and $1.0 \mathrm{~cm}$ I.D. horizontally oriented SS tube with an airflow of 14 standard $\mathrm{L} \mathrm{min}^{-1}$. The transport loss of particles in the SMPS inlets was corrected using size-dependent survival ratios of $85-100 \%$ for particles $>3 \mathrm{~nm}$.

Sulfur dioxide $\left(\mathrm{SO}_{2}\right)$, ozone $\left(\mathrm{O}_{3}\right)$, carbon monoxide $(\mathrm{CO})$, and nitrogen oxides ( $\mathrm{NO}$ and $\mathrm{NO}_{2}$ ) concentrations were measured every 1 min with Thermo Environmental Instruments (model 43i-TLE, 49i, 48i, and 42i, respectively). When gaseous $\mathrm{SO}_{2}, \mathrm{O}_{3}, \mathrm{NO}_{2}$, and $\mathrm{CO}$ data were not available, hourly $\mathrm{SO}_{2}, \mathrm{O}_{3}, \mathrm{NO}_{2}$, and $\mathrm{CO}$ were obtained from the nearby local Environmental Protection Agency (EPA) monitoring station. $\mathrm{PM}_{2.5}$ was monitored with Thermo Scientific TEOM 1405. Meteorological variables including wind speed, wind direction, relative humidity $(\mathrm{RH})$, temperature, and solar radiation flux were recorded every $1 \mathrm{~h}$ during the measurement periods. Mean concentrations of $\mathrm{PM}_{2.5}, \mathrm{SO}_{2}$, and $\mathrm{O}_{3}$ were $79 \mu \mathrm{g} \mathrm{m}^{-3}, 10$, and $48 \mathrm{ppbv}$, respective, during the whole measurement period. Therefore, we regard our measurement environment as a polluted urban atmosphere.

\subsection{Nucleation event and growth patterns}

A criterion was set to determine whether the nCNC detected sub- $3 \mathrm{~nm}$ particles in the atmosphere. The criterion was that total particle concentration reading followed the supersaturation scanning cycle of PSM so that the highest concentrations were measured at lowest cutoff sizes (see also Fig. 2 in Lehtipalo et al., 2014). However, it was possible in the stepwise inversion method that the number concentration fluctuation of $>3 \mathrm{~nm}$ particles within a 4 min scanning cycle was wrongly inverted to sub- $3 \mathrm{~nm}$ particles even when sub- $3 \mathrm{~nm}$ particles 
actually did not exist according to the above criterion. As a result, the stepwise inversion method always reported a background sub- $3 \mathrm{~nm}$ particle concentration $\left(N_{\text {sub- } 3}\right.$; i.e. the sum of $N_{1.5}, N_{1.8}, N_{2.0}, N_{2.3}, N_{2.6}$, and $N_{2.8}$ ) of $0.5 \times 10^{3}-$ $2 \times 10^{3} \mathrm{~cm}^{-3}$ in the nighttime and $3 \times 10^{3}-8 \times 10^{3} \mathrm{~cm}^{-3}$ in the daytime. Similar background levels of sub- $3 \mathrm{~nm}$ particles during non-NPF periods were also reported by other studies that used the nCNC (Kulmala et al., 2013; Lehtipalo et al., 2014; Xiao et al., 2015). Following their procedures, we did not attempt to subtract this background from $N_{\text {sub-3 }}$ reported in this study.

We defined the sub- $3 \mathrm{~nm}$ particle event as a sub- $3 \mathrm{~nm}$ particle occurrence with a $N_{\text {sub- } 3}$ higher than the background level persisting for longer than $1 \mathrm{~h}$ in the atmosphere. In this study, we used sub- $3 \mathrm{~nm}$ particle event as an approximate measure of the nucleation event. This is because (1) there was an approximately positive linear correlation between the $N_{\text {sub-3 }}$ and the nucleation rate ( $J_{1.4}$ in this study, see next section) with $R^{2}$ of 0.94 (Fig. 2), and (2) the $N_{\text {sub-3 }}$ calculation only needs nCNC scanning data and was thus more readily available than the $J_{1.4}$ calculation, which needs both $\mathrm{nCNC}$ and SMPS scanning data. A similar definition has been discussed in our previous studies (Yu et al., 2014a, b). Apparently, a sub-3 $\mathrm{nm}$ particle event did not necessarily always lead to an NPF event, but it indicated the intensity and frequency of nucleation in the atmosphere. One focus in this work was to investigate the characteristics of sub- $3 \mathrm{~nm}$ particle event.

Particle growth after nucleation is crucial to determine if nucleated particles could grow to $\mathrm{CCN}$-active sizes. We identified two growth patterns according to size spectrum characteristics in sub-3 $\mathrm{nm}$ size range (Fig. 3). In a Type A event (Fig. 3a or b), size distribution $n\left(D_{\mathrm{p}}, t\right)$ was higher at smaller sizes (e.g., $1.4-1.6 \mathrm{~nm})$ than $n\left(D_{\mathrm{p}}, t\right)$ at larger sizes (e.g., 2.7-3.0 nm). The size spectrum below $3 \mathrm{~nm}$ thus looked like a "volcano". In a Type B event (Fig. $3 \mathrm{c}$ or d), $n\left(D_{\mathrm{p}}, t\right)$ was lower at smaller sizes than $n\left(D_{\mathrm{p}}, t\right)$ at larger sizes ( "up-sidedown volcano"). For the size range $>3 \mathrm{~nm}$, depending on whether a banana-shape growth was seen, we further defined Type A1/A2 and Type B1/B2 events: particles eventually grew to a $\mathrm{CCN}$-active sizes in Type $\mathrm{A} 1$ and $\mathrm{B} 1$ events, while in Type A2 and B2 events, banana-shape particle growth to $\mathrm{CCN}$-active sizes was not seen. Therefore, Type A1 and B1 events were equivalent to conventional NPF events based on either DMPS or SMPS measurements.

Type B size distribution was more unusual since $n\left(D_{\mathrm{p}}, t\right)$ of small particles were less than $n\left(D_{\mathrm{p}}, t\right)$ of large particles in the sub- $3 \mathrm{~nm}$ size range. We excluded the possibility of deteriorated $\mathrm{nCNC}$ detection efficiencies for small particles due to high particle loading in the sample air. This is because total number concentrations of nCNC during our measurements never approached $\mathrm{nCNC}$ upper concentration limit $4 \times 10^{5} \mathrm{~cm}^{-3}$, especially in the early stage of nucleation when total particle concentration was rather low. Our nCNC was also calibrated periodically using $\mathrm{H}_{2} \mathrm{SO}_{4}-\mathrm{H}_{2} \mathrm{O}$ particles in a laboratory flow tube to ensure the detection efficiency of the

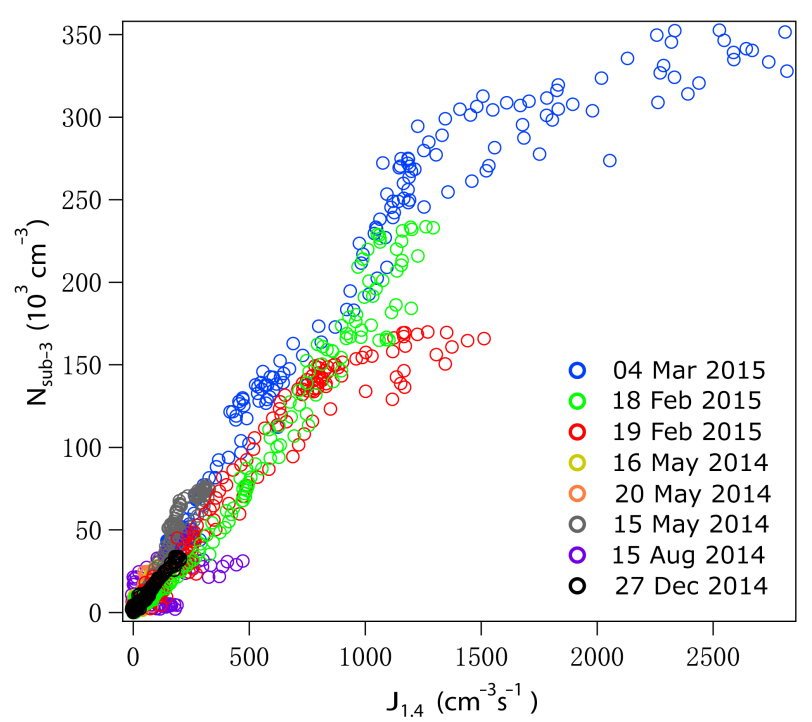

Figure 2. $N_{\text {sub-3 }}$ vs. $J_{1.4}$ in the eight nucleation events in February, May, December, and August during 2014-2015. The events were indicated by different colors (blue: 1 March 2015; green: 18 February 2015; red: 19 February 2015; purple: 15 August 2014; black: 27 December 2014; grey: 15 May 2014; orange: 20 May 2014; yellow: 16 May 2014).

nCNC. The different chemical composition of atmospheric particles could be another factor of lower detection efficiencies. It is well known that organic substances activate less readily in diethylene glycol (DEG) (e.g. Kangasluoma et al., 2014). However, it is accepted in general that larger particles have higher mass fraction of organics than smaller particles in a NPF process. If organic substances activate less readily in DEG, it should be even more difficult to activate larger particles than smaller particles. Therefore, the increasing $n\left(D_{\mathrm{p}}\right)$ with $D_{\mathrm{p}}$ (i.e. upside down volcano) could not be simply due to lower detection efficiency of organic substances.

\subsection{Formation rate and growth rate calculations with a simplified GDE method}

Conventional appearance-time method determined growth rates (hereafter, GR) during the initial period of NPF by finding the time steps when newly formed particles appeared at certain size bins and calculating the GR from the time differences between successive size bins (Kulmala et al., 2012; Lehtipalo et al., 2014). This method was often not applicable to the NPF event with high GR below $3 \mathrm{~nm}$, e.g., $0.3 \mathrm{~nm} / 4 \mathrm{~min}$ (i.e. $4.5 \mathrm{~nm} \mathrm{~h}^{-1}$ ) with size intervals of $0.3 \mathrm{~nm}$ and scanning time intervals of $4 \mathrm{~min}$ in our measurements. Furthermore, sub- $3 \mathrm{~nm}$ particles were often generated persistently throughout the daytime period. Maximum concentrations in the sub- $3 \mathrm{~nm}$ size bins could appear around noontime, which is a few hours later than the onset of nucleation. Therefore, we were not able to pinpoint correctly maximum or $50 \%$ maximum concentrations at the onset of nucleation. 

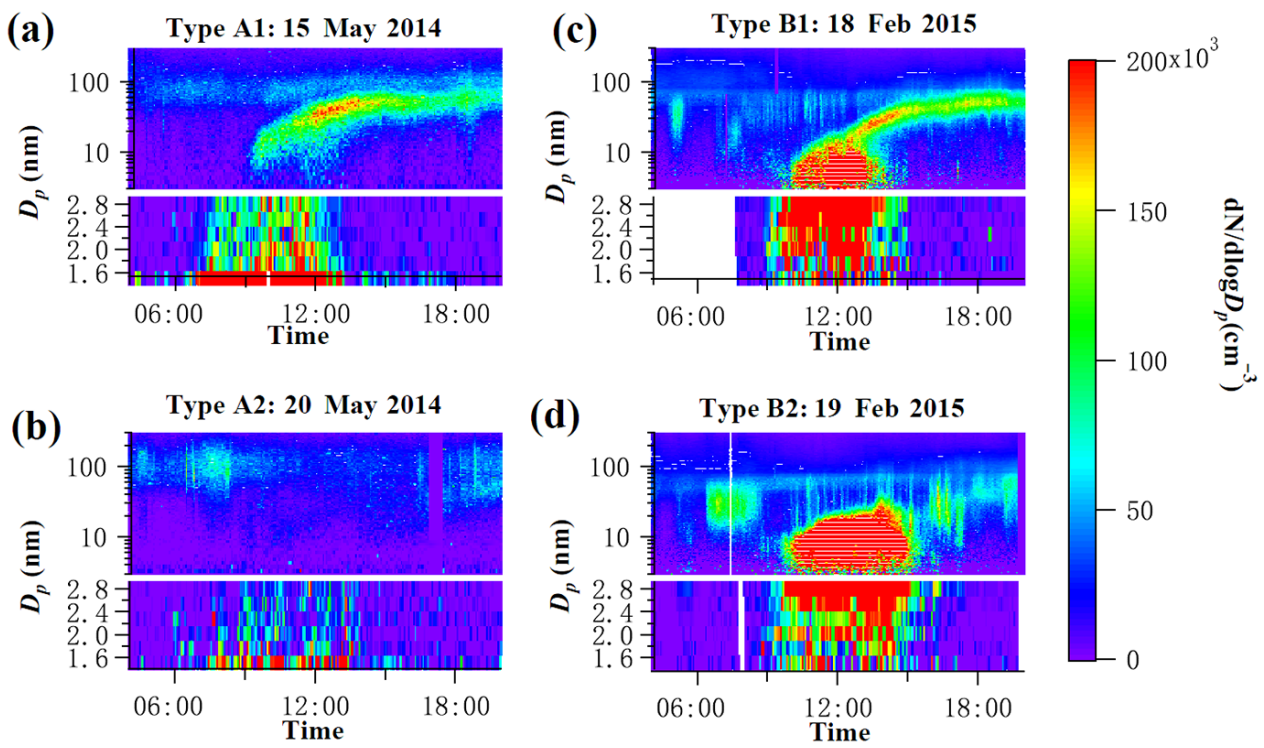

Figure 3. Size spectra of typical (a) Type A1 event on 15 May 2014, (b) Type A2 event on 20 May 2014, (c) Type B1 event on 18 February 2015, and (d) Type B2 event on 19 February 2015, during our measurement period. Size spectra from 3 to $300 \mathrm{~nm}$ (logarithmic scale) and 1.4 to $3 \mathrm{~nm}$ (linear scale) were obtained using SMPS and nCNC, respectively.

The rapid growth of small particles in the urban atmosphere was the motivation that we used an alternative method to calculate growth rate and formation rate. Here, we analyzed eight events (listed in Table 1, including both Type A1/A2 and B1/B2 events) in detail, for which complete size spectra from 1.4 to $750 \mathrm{~nm}$ were available without distorted, broken or noisy data. A total of 8 size bins were classified: 6 evenly-divided size bins in sub- $3 \mathrm{~nm}$ and 2 size bins in 3-30 nm (3-10 and 10-30 nm). For an aerosol population that is growing through simultaneous condensation and coagulation, the aerosol general dynamic equation (GDE) describes the evolution of number concentration in a size bin between particle diameters $D_{\mathrm{p} 1}$ and $D_{\mathrm{p} 2}\left(D_{\mathrm{p} 2}>D_{\mathrm{p} 1}\right)$ as

$$
\begin{aligned}
& \frac{\mathrm{d} N\left(D_{\mathrm{p} 1}, D_{\mathrm{p} 2}, t\right)}{\mathrm{d} t}=J\left(D_{\mathrm{p} 1}, t\right)-J\left(D_{\mathrm{p} 2}, t\right) \\
& \quad-\operatorname{CoagSnk}\left(D_{\mathrm{p} 1}, D_{\mathrm{p} 2}, t\right)+\operatorname{CoagSrc}\left(D_{\mathrm{p} 1}, D_{\mathrm{p} 2}, t\right),
\end{aligned}
$$

where $N\left(D_{\mathrm{p} 1}, D_{\mathrm{p} 2}, t\right)$ is the number concentration from $D_{\mathrm{p} 1}$ to $D_{\mathrm{p} 2}$, inverted from $\mathrm{nCNC}$ or SMPS scanning data. $J$ is condensational growth flux (i.e. particle formation rate) across the lower $\left(D_{\mathrm{p}, 1}\right)$ or upper $\left(D_{\mathrm{p}, 2}\right)$ boundaries of a size bin. In the first size bin of $1.4-1.6 \mathrm{~nm}, J(1.4 \mathrm{~nm}, t)$, or simply $J_{1.4}$, is the unknown formation rate of the smallest particles that we measured.

$\operatorname{Coag} \operatorname{Snk}\left(D_{\mathrm{p} 1}, D_{\mathrm{p} 2}, t\right)$ and $\operatorname{CoagSrc}\left(D_{\mathrm{p} 1}, D_{\mathrm{p} 2}, t\right)$ are the sink and source terms defining the coagulation out of and into the size bin between $D_{\mathrm{p} 1}$ and $D_{\mathrm{p} 2}$. Assuming bin $k$ has lower boundary $D_{\mathrm{p} 1}$ and upper boundary $D_{\mathrm{p} 2}$,

$$
\begin{aligned}
& \operatorname{CoagSnk}\left(D_{\mathrm{p} 1}, \mathrm{D}_{\mathrm{p} 2}, t\right)= \\
& N(k, t) \sum_{i=1}^{98}\left(1-\theta_{k, i, k}\right) K_{k, i} N(i, t), \\
& \operatorname{CoagSrc}\left(D_{\mathrm{p} 1}, \mathrm{D}_{\mathrm{p} 2}, t\right)= \\
& \frac{1}{2} \sum_{i=1}^{k-1} \sum_{j=1}^{k-1} \theta_{i, j, k} K_{i, j} N(j, t) N(i, t) .
\end{aligned}
$$

Here $N(i, t)$ is the number concentration of bin $i . K_{i, j}$ is the coagulation kernel for a collision between particles from bins $i$ and $j$. Probability coefficient $\theta_{i, j, k}=1$, if the volume sum of two coagulating particles $\left(v_{i}+v_{j}\right.$, here the volume is calculated from the center diameter of a bin) is within the volume boundaries of bin $k$. Otherwise $\theta_{i, j, k}=0$. The particle coagulation of total 98 bins was considered, but the coagulation terms were only needed to be calculated for the smallest 8 bins from 1.4 to $30 \mathrm{~nm}$. According to our calculation, $\operatorname{Coag} \operatorname{Src}\left(D_{\mathrm{p} 1}, D_{\mathrm{p} 2}, t\right)$ accounted for only $0-0.8 \%$ of the total particle flux into a bin (i.e. $\operatorname{Coag} \operatorname{Src}\left(D_{\mathrm{p} 1}, D_{\mathrm{p} 2}\right.$, $\left.t)+J\left(D_{\mathrm{p} 1}, t\right)\right)$ in the sub- $3 \mathrm{~nm}$ size range. This implied that self-coagulation played a negligible role and most of the production flux into a bin is due to condensational growth from gas molecules.

The GDE here is the same as the Eq. (1) by Kuang et al. (2012). In their method, gaseous $\mathrm{H}_{2} \mathrm{SO}_{4}$ was measured simultaneously and a constant $\operatorname{GR}\left(D_{\mathrm{p}}, t\right) / \mathrm{GR}_{\mathrm{H}_{2} \mathrm{SO}_{4}}\left(D_{\mathrm{p}}, t\right)$ ratio at a given size over time was assumed. Their $\operatorname{GR}\left(D_{\mathrm{p}}, t\right)$ was then solved by fitting the GDE to the measured size distributions. In our study, however, we did not measure gaseous 
Table 1. Activation diameter $\left(D_{\mathrm{p}, \text { act }}\right)$, maximum growth rate in 1.4-3 nm $\left(\mathrm{GR}_{\mathrm{max}, 1.4-3}\right)$, overall growth rate in $1.4-3 \mathrm{~nm}\left(\mathrm{GR}_{1.4-3}\right)$, overall growth rate in 3-20 $\mathrm{nm}\left(\mathrm{GR}_{3-20}\right)$, nucleation rate $\left(J_{1.4}\right)$, condensation sink $(\mathrm{CS})$, and temperature $(T)$ of selected nucleation events. Estimated gas-phase condensing vapor concentrations $C_{\mathrm{elvoc}}$, pure saturation concentration of condensing vapor over flat surface $C_{\mathrm{elvoc}}^{*}$, and the Mikkonen $\mathrm{H}_{2} \mathrm{SO}_{4}$ proxy are shown in right three columns. All data were for the time periods with maximum nucleation rates.

\begin{tabular}{|c|c|c|c|c|c|c|c|c|c|c|c|}
\hline Type & Date & $\begin{array}{r}D_{\mathrm{p}, \text { act }} \\
(\mathrm{nm})\end{array}$ & $\begin{array}{r}\mathrm{GR}_{\max , 1.4-3} \\
\quad\left(\mathrm{~nm} \mathrm{~h}^{-1}\right)\end{array}$ & $\begin{array}{r}\mathrm{GR}_{1.4-3} \\
\left(\mathrm{~nm} \mathrm{~h}^{-1}\right)\end{array}$ & $\begin{array}{r}\mathrm{GR}_{3-20} \\
\left(\mathrm{~nm} \mathrm{~h}^{-1}\right)\end{array}$ & $\begin{array}{r}J_{1.4} \\
\left(\mathrm{~cm}^{-3} \mathrm{~s}^{-1}\right)\end{array}$ & $\begin{array}{r}T \\
\left({ }^{\circ} \mathrm{C}\right)\end{array}$ & $\begin{array}{r}\mathrm{CS} \\
\left(10^{-2} \mathrm{~s}^{-1}\right)\end{array}$ & $\begin{array}{r}\text { Mikkonen } \\
\mathrm{H}_{2} \mathrm{SO}_{4} \text { proxy } \\
\left(\mathrm{cm}^{-3}\right)\end{array}$ & $\begin{array}{r}C_{\text {elvoc }} \\
\left(\mathrm{cm}^{-3}\right)\end{array}$ & $\begin{array}{c}C_{\text {elvoc }}^{*} \\
\left(\mathrm{~cm}^{-3}\right)\end{array}$ \\
\hline A1 & 15 May 2014 & 2.4 & 6.4 & 3.6 & 7.7 & $3.0 \times 10^{2}$ & 20.8 & 1.6 & $2.9 \times 10^{7}$ & $3.5 \times 10^{7}$ & $6.3 \times 10^{6}$ \\
\hline $\mathrm{A} 1$ & 15 Aug 2014 & 2.4 & 14.5 & 7.1 & 7.7 & $2.0 \times 10^{2}$ & 26.1 & 1.8 & $3.1 \times 10^{7}$ & $8.5 \times 10^{7}$ & $2.1 \times 10^{7}$ \\
\hline A2 & 16 May 2014 & 2.4 & 3.8 & 1.9 & 0 & 95 & 25.3 & 1.9 & $1.4 \times 10^{7}$ & $2.5 \times 10^{7}$ & $4.6 \times 10^{6}$ \\
\hline A2 & 20 May 2014 & 2.2 & 2.9 & 1.6 & 0 & 92 & 24.1 & 1.9 & $1.3 \times 10^{7}$ & $1.7 \times 10^{7}$ & $3.3 \times 10^{6}$ \\
\hline B1 & 18 Feb 2015 & 1.6 & 25.9 & 4.4 & 6.0 & $1.1 \times 10^{3}$ & 8.2 & 3.3 & $3.9 \times 10^{7}$ & $1.4 \times 10^{8}$ & $3.0 \times 10^{7}$ \\
\hline $\mathrm{B} 1$ & 27 Dec 2014 & 1.6 & 17.7 & 4.2 & 5.5 & $1.9 \times 10^{2}$ & 7.6 & 2.8 & $3.5 \times 10^{7}$ & $1.1 \times 10^{8}$ & $2.2 \times 10^{7}$ \\
\hline B2 & 19 Feb 2015 & 1.9 & 25.0 & 8.9 & 10.1 & $8.0 \times 10^{2}$ & 7.4 & 3.2 & $3.7 \times 10^{7}$ & $1.7 \times 10^{8}$ & $5.2 \times 10^{7}$ \\
\hline B2 & 4 Mar 2015 & 1.9 & 18.0 & 5.8 & 8.7 & $2.5 \times 10^{3}$ & 3.9 & 2.2 & $4.8 \times 10^{7}$ & $1.3 \times 10^{8}$ & $1.1 \times 10^{7}$ \\
\hline
\end{tabular}

$\mathrm{H}_{2} \mathrm{SO}_{4}$. Instead, $J(30 \mathrm{~nm}, t)$ in the largest size bin, which is the condensational growth flux out of $30 \mathrm{~nm}$, was set to zero. This simplification was valid in the four Type A2/B2 events when particles never grew to $>30 \mathrm{~nm}$ (4 March, 19 February, 20 and 16 May). In the remaining four Type A1/B1 events (18 February, 27 December, 15 May, and 15 August), this was also valid during the early NPF period when particles did not grow out of $30 \mathrm{~nm}$ and during the late NPF period when particles grew out of $30 \mathrm{~nm}$ completely. During the middle period of events (usually around 11:00-14:00 LT, local time), $J(30 \mathrm{~nm}, t)$ was underestimated and thus $J_{1.4}$ could be regarded as a lower estimate. In the four Type A2/B2 events, our calculation showed that $J_{10}$ was only $0-4 \%$ of $J_{1.4}$. Xiao et al. (2015) and Kulmala et al. (2013) measured both $J_{1.5}$ and $J_{3}$ using the appearance-time method. Their $J_{3}$ was less than $7 \%$ of $J_{1.5}$. Furthermore, $J_{30} / J_{1.4}$ ratio should be even smaller than $J_{10} / J_{1.4}$ or $J_{3} / J_{1.5}$ ratios, considering the eight events were carefully selected to ensure all sub- $30 \mathrm{~nm}$ particles were grown from nucleation (not emitted directly from emission sources like vehicular engine). All these evidences supported the fact that even if $J_{30}$ was set to $0, J_{1.4}$ would not be underestimated more than $7 \%$ when particles grew to $>30 \mathrm{~nm}$ on 18 February, 27 December, 15 May, and $15 \mathrm{Au}$ gust.

Equation (1) requires the balance of condensational growth $(J)$, coagulation terms (CoagSnk and CoagSrc), and the changing rate of particle number concentration $(\mathrm{d} N / \mathrm{d} t)$. Using Eq. (1) we can therefore calculate the nucleation rate $J(1.4 \mathrm{~nm}, t)$ and formation rates $J\left(D_{\mathrm{p}}, t\right)$ across all size bin boundaries from 1.6 to $10 \mathrm{~nm}$. After the formation rates $J\left(D_{\mathrm{p}}, t\right)$ were obtained, $\operatorname{GR}\left(D_{\mathrm{p}}, t\right)$ was calculated from $J\left(D_{\mathrm{p}}, t\right) / \mathrm{n}\left(D_{\mathrm{p}}, t\right)$, where $n\left(D_{\mathrm{p}}, t\right)$ is the size distribution calculated as $n\left(D_{\mathrm{p}}, t\right)=\frac{\mathrm{d} N(t)}{\mathrm{d} D_{\mathrm{p}}}$ for each size bin. On the other hand, the appearance-time method could still be applied to (1) the size range of $>3 \mathrm{~nm}$ where size intervals were large $(2-6 \mathrm{~nm})$, and (2) the size range of $<3 \mathrm{~nm}$ when GR was small. The results from the appearance-time method will also be shown in the next section.

\section{Results and discussion}

Sections 3.1, 3.2-3.4, 3.5, and 3.6 were organized, respectively, to address the following four issues: (1) seasonal variation, diurnal variation, and limiting factors of nucleation events (represented by sub- $3 \mathrm{~nm}$ particle event) in the polluted urban atmosphere; (2) time- and size-dependent nucleation rate and growth rate of sub- $3 \mathrm{~nm}$ particles, and their implications for nucleation and growth mechanisms; (3) inhibited particle growth to $\mathrm{CCN}$-active sizes in strong nucleation events of Type B2; and (4) the comparison with other two studies involving sub- $3 \mathrm{~nm}$ particle measurements in the YRD megacities.

\subsection{Seasonal and diurnal variations of nucleation event}

As seen from Fig. 2, there was an approximate linear correlation between $N_{\text {sub-3 }}$ and $J_{1.4}$ with the slope of $N_{\text {sub-3 }} / J_{1.4}$ equal to $\sim 160$. This seemed to suggest that the average residence time of new particles in the sub- $3 \mathrm{~nm}$ size range was $160 \mathrm{~s}$ before they were scavenged due to coagulation or grew out of $3 \mathrm{~nm}$. The sub- $3 \mathrm{~nm}$ particles observed at the present work were thus formed in situ in the urban atmosphere and not likely to be carried-over by air transport. In this section we used a sub-3 $\mathrm{nm}$ particle event as an approximate measure of nucleation.

We observed significant seasonal characteristics of nucleation event (Fig. 4). Nucleation was rare and weak in summer, while it was commonly observed in all other seasons. During our measurements from 2014 to 2015, nucleation events occurred on $81 \%$ of all spring observation days (May 2014), $53 \%$ in early summer (June 2014), $10 \%$ in summer (August and September 2014), and $64 \%$ in winter (December 2014, February and March 2015). We compared intensity $\left(N_{\text {sub-3 }}\right)$ and frequency of nucleation events, as well as 

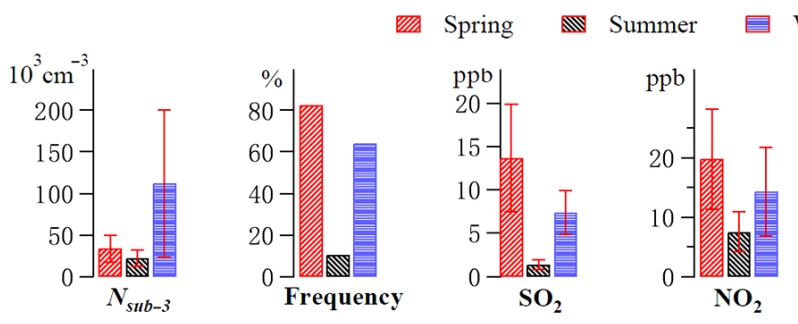

Winter
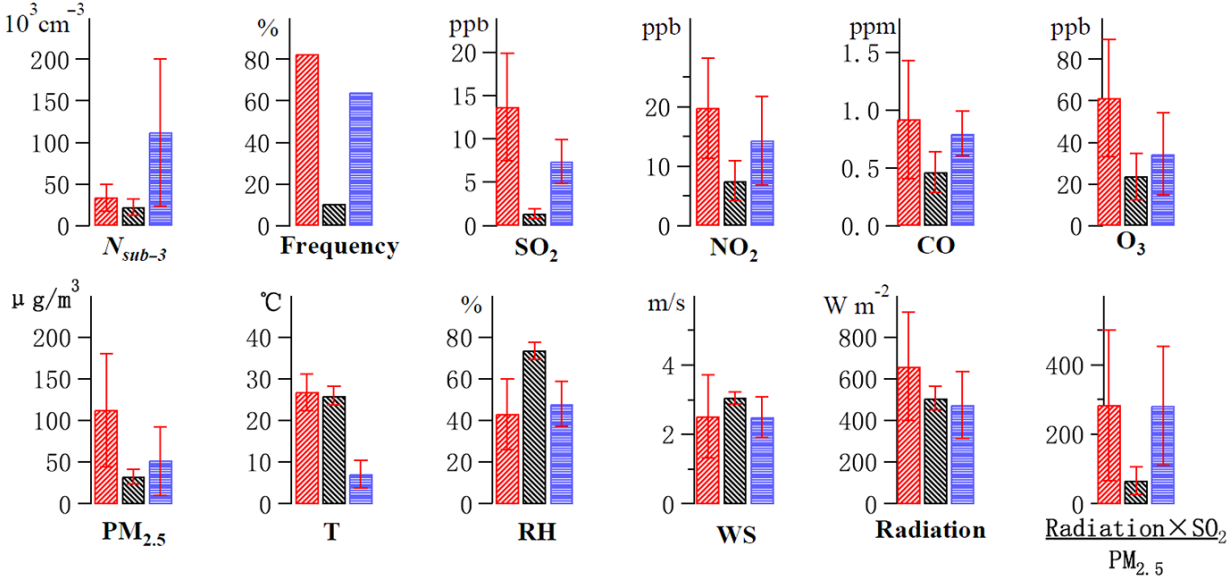

Figure 4. Mean and standard deviation of event-averaged $N_{\text {sub-3 }}$, anthropogenic trace gases $\left(\mathrm{SO}_{2}, \mathrm{NO}_{2}, \mathrm{CO}_{\text {and }} \mathrm{O}_{3}\right), \mathrm{PM}_{2.5}$, and meteorological variables (temperature, $\mathrm{RH}$, wind speed, WS, solar radiation, and radiation $\times \mathrm{SO}_{2} / \mathrm{PM}_{2.5}$ ) for nucleation events in spring $(n=17$ ), summer $(n=3)$ and winter $(n=14)$. Nucleation frequency (the percentage of event days out of total measurement days) was also shown.

meteorological variables (temperature, $\mathrm{RH}$, wind speed, and solar radiation flux) and gaseous pollutants $\left(\mathrm{SO}_{2}, \mathrm{NO}_{2}, \mathrm{CO}\right.$, and $\mathrm{O}_{3}$ ) for spring, summer, and winter seasons. June was not shown in Fig. 4 for comparison, because it was a transit season from spring (May) to summer (August and September). The data were first averaged over the entire event period for each event, and we then used event-averaged data to create box and whistler plots for the three seasons. $\mathrm{PM}_{2.5}$ was used here as a surrogate of condensational sink (CS), because of the more ready availability of $\mathrm{PM}_{2.5}$ data than SMPS data.

As shown in Fig. 4, nucleation in summer was characterized by the lowest frequency, the lowest $N_{\text {sub-3 }}(2.2 \times$ $10^{4} \mathrm{~cm}^{-3}$ ), and a short nucleation period (only $1-2 \mathrm{~h}$ ). Strict emission control measures during the 2014 Youth Olympic Games resulted in relatively low $\mathrm{PM}_{2.5}$ level $\left(32 \pm 8 \mu \mathrm{g} \mathrm{m}^{-3}\right)$, which should favor nucleation. However, relatively low $\mathrm{SO}_{2}$ concentration (1.4 $\left.\pm 0.6 \mathrm{ppbv}\right)$, high temperature $\left(26 \pm 2{ }^{\circ} \mathrm{C}\right)$, and high $\mathrm{RH}(74.3 \pm 4.2 \%)$ might not be in favor of nucleation. A simple $\mathrm{H}_{2} \mathrm{SO}_{4}$ proxy (Radiation $\times \mathrm{SO}_{2} / \mathrm{PM}_{2.5}$ ) indicated that summer $\mathrm{H}_{2} \mathrm{SO}_{4}$ concentration was likely to be the lowest among the three seasons, which could explain low nucleation intensity/frequency.

We further examined diurnal variations of $N_{\text {sub-3 }}$ and other variables on event and non-event days in winter (Fig. 5). Since nucleation in winter was characterized by a Type B event ("up-side-down volcano" below $3 \mathrm{~nm}$ ), event days were further divided into Type B1 and Type B2 events depending on whether banana-shape particle growth was seen. The difference between Type B1 and B2 will be discussed later in Sect. 3.5. During the non-event days, $N_{\text {sub-3 }}$ ranged from $2.4 \times 10^{3} \mathrm{~cm}^{-3}$ in the night to $8.0 \times 10^{3} \mathrm{~cm}^{-3}$ in the day, which was close to background levels. During the event days, $N_{\text {sub-3 }}$ in the night was close to that of non-event days, but could reach $8 \times 10^{4}-20 \times 10^{4} \mathrm{~cm}^{-3}$ in the middle of the day.
This was more than 10 times higher than those on the nonevent days. From Fig. 5 we can see that non-event day had higher concentrations of anthropogenic precursors (indicated by $\mathrm{SO}_{2}, \mathrm{NO}_{2}$, and $\mathrm{CO}$ ), but nucleation seemed to be limited by higher pre-existing particle surface area (indicated by $\mathrm{PM}_{2.5}$ ), higher temperature and $\mathrm{RH}$, and lower radiation flux. Photochemistry indicator $\mathrm{O}_{3}$ was also lower during nonevent days.

Nucleation in spring was characterized by the highest frequency $(81 \%)$ among all seasons. The highest gaseous pollutant concentration of $\left(\mathrm{H}_{2} \mathrm{SO}_{4}\right.$ proxy, $\mathrm{SO}_{2}, \mathrm{NO}_{2}, \mathrm{CO}$, and $\mathrm{O}_{3}$ ) and radiation seemed to be the favorable factors to explain this. However, $N_{\text {sub-3 }}$ in spring $\left(3.3 \times 10^{4} \mathrm{~cm}^{-3}\right)$ was much lower than that in winter $\left(11.2 \times 10^{4} \mathrm{~cm}^{-3}\right)$. Unfavorable factors included high pre-existing particle surface area $\left(\mathrm{PM}_{2.5}: 112 \pm 68 \mu \mathrm{g} \mathrm{m}^{-3}\right)$ and high temperature $\left(27 \pm 4{ }^{\circ} \mathrm{C}\right)$ in spring. Integrating the above seasonal and diurnal variation information in Figs. 4 and 5, we tentatively identified that the limiting factors for nucleation in our urban atmosphere were (1) radiation, temperature, $\mathrm{RH}$, and CS in winter and spring, and (2) temperature, $\mathrm{RH}$, and available gaseous precursors in summer.

Out of the total of 90 measurement days, 4 March 2015 in winter was the only day that we observed significant nocturnal nucleation. Sunrise and sunset were at 06:29 and 18:00 LT on 4 March, but nucleation was observed persistently from 04:00-20:00 LT. $N_{\text {sub-3 }}$ increased from $3.5 \times$ $10^{3} \mathrm{~cm}^{-3}$ at 04:00 LT to $6.3 \times 10^{4} \mathrm{~cm}^{-3}$ before sunrise. During 10:00-11:00 LT, peak $N_{\text {sub-3 }}$ reached $3 \times 10^{4} \mathrm{~cm}^{-3}$, 3 times higher than the average of all other event days in winter. Apparently, nocturnal nucleation on 4 March could not be explained as carry-over of daytime particles nor being associated with photochemistry. This implied the existence of a certain dark nucleation source. There are a number of 

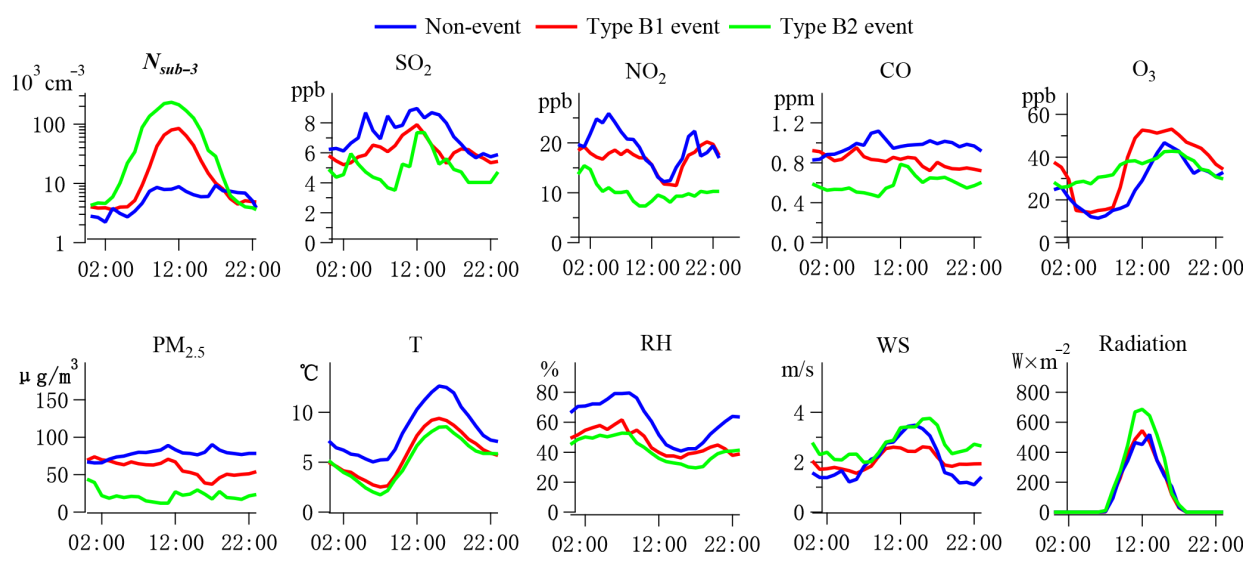

Figure 5. Diurnal variations of mean $N_{\text {sub-3 }}$, anthropogenic trace gases $\left(\mathrm{SO}_{2}, \mathrm{NO}_{2}, \mathrm{CO}\right.$, and $\left.\mathrm{O}_{3}\right), \mathrm{PM}_{2.5}$, and meteorological variables (temperature, RH, wind speed, and solar radiation flux) on non-event days ( $n=8$, blue line) and event days $(n=3$ for Type B1 event, red line and $n=6$ for Type B2 event, green line) during winter measurement period.

observations that have also shown nighttime particle formation events in various atmospheric conditions (Junninen et al., 2008; Lehtipalo et al., 2011; Lee et al., 2008; Ortega et al., 2009, 2012; Russell et al., 2007; Suni et al., 2008; Svenningsson et al., 2008; Yu et al., 2014a), but the mechanisms behind the nocturnal nucleation are yet still highly speculative. With our instrument capability in this work, we could not deduce any valuable information on the nocturnal nucleation mechanism, except that we found that the air mass on 4 March was relatively clean (both CS and gases, mean CS: $0.15 \mathrm{~s}^{-1}$ ), and temperature and $\mathrm{RH}$ (mean: $4.4^{\circ} \mathrm{C}$ and $33 \%$ ) were favorable for nucleation.

\subsection{Size- and time-dependent formation rates of sub-3 $\mathrm{nm}$ particles}

We observed 23 Type A events and 9 Type B events during the measurements. The different size distribution patterns (Fig. 3) were probably linked to the mechanism or intensity of nucleation and growth. To address this issue, we first compared the formation rates and growth rates in two types of events. Formation rates $J$ of 1.4, 1.6, 1.9, 2.2, 2.4, 2.7, and $3.0 \mathrm{~nm}$ particles were shown in Fig. 6 (upper panels) for typical Type A and Type B events. It is obvious that $J_{1.4}$ was much higher on 18 February (Type B) than that on 15 May (Type A). A clear time dependence of $J$ was observed. For example, $J_{1.4}$ was $60 \mathrm{~cm}^{-3} \mathrm{~s}^{-1}$ at the onset of the nucleation event on 15 May and increased to $300 \mathrm{~cm}^{-3} \mathrm{~s}^{-1}$ in the middle of the day. In the Type B event on 19 February, the initial and peak $J_{1.4}$ were $2.1 \times 10^{2}$ and $1.2 \times 10^{3} \mathrm{~cm}^{-3} \mathrm{~s}^{-1}$, respectively. Therefore, our method provided more information of nucleation than conventional calculation methods that usually showed only an averaged $J$ at the onset of a nucleation event. Our method was also different from Kulmala et al. (2013). Their time-dependent formation rate on an event day was equal to size distribution $n\left(D_{\mathrm{p}}, t\right)$ times a con- stant growth rate at the onset of the event obtained with the appearance-time method.

The diurnal variation of $J$ implied that nucleation was probably linked to sunlight induced photochemistry. We calculated the correlations between $J_{1.4}$ and an $\mathrm{H}_{2} \mathrm{SO}_{4}$ proxy for the eight events of our interest. The $\mathrm{H}_{2} \mathrm{SO}_{4}$ proxy was calculated following $\left[\mathrm{H}_{2} \mathrm{SO}_{4}\right]=8.21 \times 10^{-3} \mathrm{k}$. Radiation $\left[\mathrm{SO}_{2}\right]^{0.62} \cdot(\mathrm{CS} \cdot \mathrm{RH})^{-0.13}$ (Eq. 8 of Mikkonen et al., 2011), where $k$ is the temperature-dependent reactionrate constant. Figure 7a shows that good linear correlation was usually seen for every single event with $R^{2}$ ranging from 0.72 to 0.86 for six out of eight events. A moderate $R^{2}$ of 0.56 was obtained for 15 August. $R^{2}$ was lowest (0.34) on 4 March 2015. This is not surprising because we know 4 March was the only day with nocturnal nucleation during the measurement period. The $\mathrm{H}_{2} \mathrm{SO}_{4}$ proxy was also calculated using the derivation of Petäjä et al. (2009), which resulted in lower $R^{2}$ of $\log J_{1.4}$ vs. $\log \left[\mathrm{H}_{2} \mathrm{SO}_{4}\right]$ for all eight events. Therefore, in this study we used the Mikkonen $\mathrm{H}_{2} \mathrm{SO}_{4}$ proxy, as it was derived with a more comprehensive data sets than Petäjä et al. (2009). The slopes of $\log J_{1.4}$ vs. $\log \left[\mathrm{H}_{2} \mathrm{SO}_{4}\right]$ were close to 1 in all events $(0.82-1.17$, excluding $4 \mathrm{March}$ ), indicating activation theory can explain the nucleation mechanism in our urban atmosphere.

If data points of all eight events were put together, the linear correlation between $\mathrm{H}_{2} \mathrm{SO}_{4}$ proxy and $J_{1.4}$ deteriorated (slope $=1.1, R^{2}=0.17$, Fig. $7 \mathrm{~b}$ ). In spite of considerable scattering, most data points are located between $J_{1.4}=$ $10^{-4.1} \times\left[\mathrm{H}_{2} \mathrm{SO}_{4}\right]$ and $J_{1.4}=10^{-6.3} \times\left[\mathrm{H}_{2} \mathrm{SO}_{4}\right]$. An interesting finding was that the scattering of $J_{1.4} \mathrm{vs}$. $\left[\mathrm{H}_{2} \mathrm{SO}_{4}\right]$ proxy among all eight events was probably due to temperature or season change (Fig. 7b). More specifically, with the same level of $\mathrm{H}_{2} \mathrm{SO}_{4}$ proxy, $J_{1.4}$ was higher in winter with lower temperatures than in spring/summer with higher temperatures. There were two possibilities behind the deteriorated linear correlation between the $\mathrm{H}_{2} \mathrm{SO}_{4}$ proxy and $J_{1.4}$ : (1) in- 

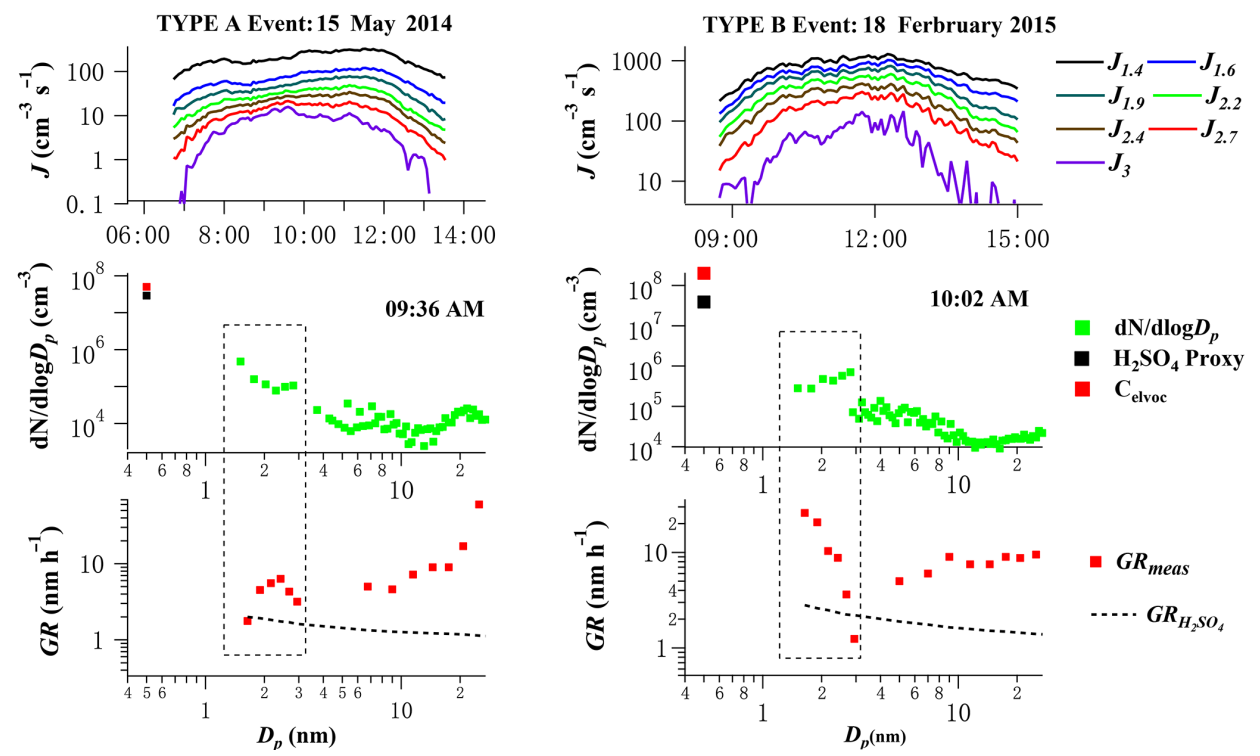

Figure 6. Upper: formation rates (or equivalently, particle growth fluxes) of 1.4, 1.6, 1.9, 2.2, 2.4, 2.7, and 3.0 nm cluster/particles on $15 \mathrm{May}$ 2014 (Type A1 event) and 18 February 2015 (Type B1 event). Middle: particle size distribution (d $N / \operatorname{dlog} D_{\mathrm{p}}$, green square) selected during the two events (09:36 and 10:02 LT). Lower: particle growth rates measured during the same time periods (GR meas, red square). Also shown

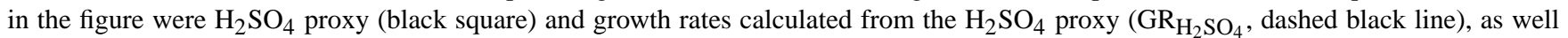
as the calculated ELVOC concentration $\left(C_{\text {elvoc }}\right.$, red square, see Eq. 5) during the same time periods. Dashed boxes in the lower panels highlighted the size distributions and growth rates between 1.4 and $3 \mathrm{~nm}$ measured with $\mathrm{nCNC}$.

accurate $\mathrm{H}_{2} \mathrm{SO}_{4}$ proxy and (2) other varying factors in nucleation mechanism. First, it was very likely that $\mathrm{H}_{2} \mathrm{SO}_{4}$ concentrations in our polluted urban atmosphere were overestimated by the $\mathrm{H}_{2} \mathrm{SO}_{4}$ proxy of Mikkonen et al. (2011), which was based on statistic regression of historical data sets from a relatively clean Europe/USA atmosphere. The extent of overestimation may vary with the levels of predictor variables (e.g., $\mathrm{SO}_{2}$, temperature, CS). Mean $\mathrm{SO}_{2}$ mixing ratios were 10.5 and $7.3 \mathrm{ppbv}$ in spring/summer and winter during our measurements, respectively. These were 1 order of magnitude higher than $\mathrm{SO}_{2}$ mixing ratios at the six European and USA sites (mean values: 0.23-3.4 ppbv, Mikkonen et al., 2011). Our CS in the eight events was on the order of magnitude of $10^{-2} \mathrm{~s}^{-1}$, again higher than $10^{-3} \mathrm{~s}^{-1}$ in Mikkonen et al. (2011). Mikkonen et al. (2011) had already pointed out that the predictive ability was lower for long-term data due to atmospheric condition changes in different seasons.

Second, organic condensing vapor concentrations in particle growth events were higher in winter than those in spring/summer (Table 1, see Sect. 3.4). If the organics were also involved in nucleation, $J_{1.4}$ should be enhanced in winter. The enhancement of nucleation by organics (most likely anthropogenic organics in our urban atmosphere) could be supported by the comparison of $J_{1.4}$ dependences on $\mathrm{H}_{2} \mathrm{SO}_{4}$ between our study and the measurements in the boreal forest: besides possible $\mathrm{H}_{2} \mathrm{SO}_{4}$ overestimation, $J_{1.4}=$ $10^{-4.1} \times\left[\mathrm{H}_{2} \mathrm{SO}_{4}\right]-10^{-6.3} \times\left[\mathrm{H}_{2} \mathrm{SO}_{4}\right]$ in our sites was much higher than $J_{1.5}=1.06 \times 10^{-7}\left[\mathrm{H}_{2} \mathrm{SO}_{4}\right]^{1.1}$ in Hyytiälä dur- ing active aerosol formation periods (Kulmala et al., 2013). At last, low temperature itself might enhance nucleation in winter (Brus et al., 2011) via increasing the saturation ratios of all nucleation precursors (e.g., water, $\mathrm{H}_{2} \mathrm{SO}_{4}$, organics).

\subsection{Size- and time-dependent growth rates of sub-3 nm particles}

Particle size distribution $n\left(D_{\mathrm{p}}\right)$ and corresponding $\operatorname{GR}\left(D_{\mathrm{p}}\right)$ at an instant in time during the events were shown in Fig. 6 middle and lower panels. A local minimum of $n\left(D_{\mathrm{p}}\right)$ at $2.4 \mathrm{~nm}$, followed by a local maximum somewhere between 2.5 and $10 \mathrm{~nm}$, was seen on 15 May 2014. Such size distribution characteristics on 15 May 2014, as well as on all other Type A event days, was also observed by Kulmala et al. (2013) in the boreal forest (Fig. 1A and S9A in their paper) and by Jiang et al. (2011b) in the urban area of Atlanta, USA (Fig. 1 in their paper). We further examined the growth rates in the size range of $1-3 \mathrm{~nm}$ on 15 May 2014. It was shown that there was a local maximum of $\operatorname{GR}\left(D_{\mathrm{p}}\right)$ at $2.4 \mathrm{~nm}$. This could explain why $n\left(D_{\mathrm{p}}\right)$ was increasing in $2.4-3 \mathrm{~nm}$ size range: when particle condensational flow out of a size bin was slowed down, it was possible that particles flowing into the size bin accumulated, leading to particle number increase in the bin.

We saw more unusual behaviors of $n\left(D_{\mathrm{p}}\right)$ and $\operatorname{GR}\left(D_{\mathrm{p}}\right)$ in the Type B event on 18 February (Fig. 6 right panels): $\operatorname{GR}\left(D_{\mathrm{p}}\right)$ decreased monotonically in the size range of 1.4$3 \mathrm{~nm}$, and accordingly $n\left(D_{\mathrm{p}}\right)$ increased monotonically at the same time. A high $\operatorname{GR}\left(D_{\mathrm{p}}\right)$ of $25 \mathrm{~nm} \mathrm{~h}^{-1}$ was observed 

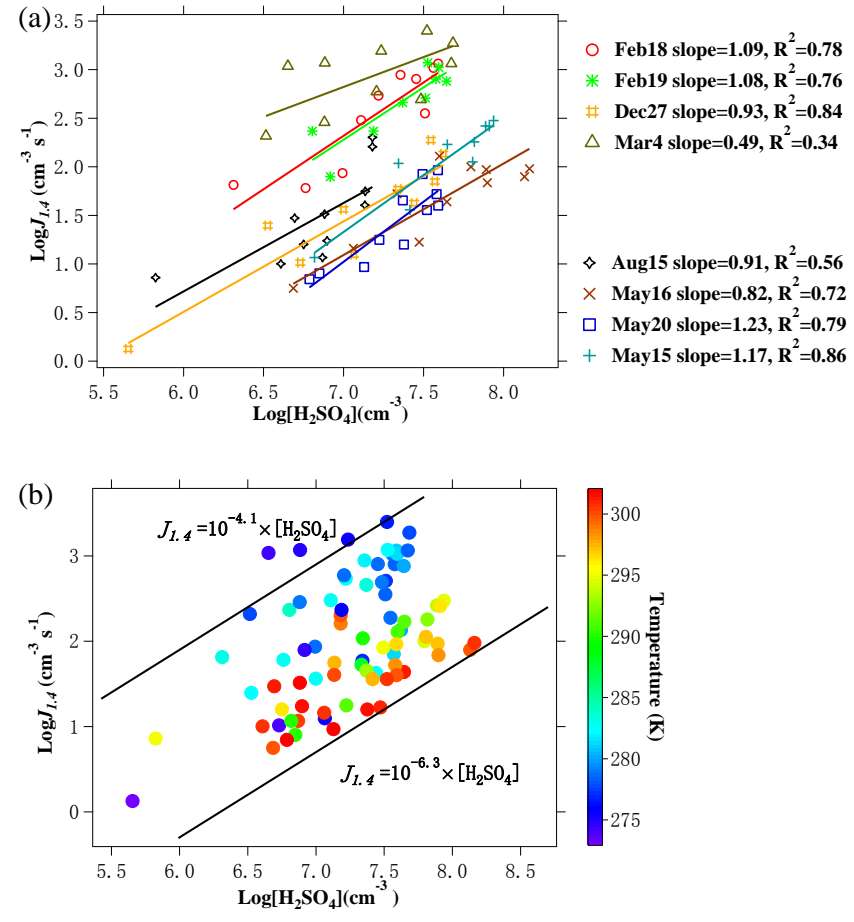

Figure 7. (a) Correlations between $\log J_{1.4}$ and $\log \left[\mathrm{H}_{2} \mathrm{SO}_{4}\right]$ for the eight events. $\mathrm{H}_{2} \mathrm{SO}_{4}$ proxy was calculated according to Mikkonen et al. (2011). $J_{1.4}$ and $\left[\mathrm{H}_{2} \mathrm{SO}_{4}\right]$ were synchronized to $1 \mathrm{~h}$ that was the time resolution of solar radiation data. The colored lines showed linear fits to the data of every single event. (b) The same data set as panel (a), but with symbol color to indicate ambient temperature. Two black lines showed the linear dependences of $J_{1.4}=10^{-4.1} \times\left[\mathrm{H}_{2} \mathrm{SO}_{4}\right]$ and $J_{1.4}=10^{-6.3} \times\left[\mathrm{H}_{2} \mathrm{SO}_{4}\right]$, between which most of data points located.

at $1.6 \mathrm{~nm}$ and $\mathrm{GR}\left(D_{\mathrm{p}}\right)$ decreased rapidly to $1.7 \mathrm{~nm} \mathrm{~h}^{-1}$ at $\sim 3 \mathrm{~nm}$. If we consider that $\operatorname{GR}\left(D_{\mathrm{p}}\right)$ below $1.6 \mathrm{~nm}$ would eventually decrease due to strong Kelvin effect of all possible precursors $\left(\mathrm{H}_{2} \mathrm{SO}_{4}\right.$ or organics), the overall trend of $\operatorname{GR}\left(D_{\mathrm{p}}\right)$ in the Type B event was in fact the same as Type A: for the smallest clusters, growth rate was small (possibly below $1 \mathrm{~nm} \mathrm{~h}^{-1}$ ) and increased with $D_{\mathrm{p}}$. It reached a local maximum somewhere between 1 and $3 \mathrm{~nm}$, after which $\mathrm{GR}\left(D_{\mathrm{p}}\right)$ decreased with $D_{\mathrm{p}}$. For a typical NPF event, $\operatorname{GR}\left(D_{\mathrm{p}}\right)$ would eventually increase again after a local minimum between 3 and $10 \mathrm{~nm}$. The difference between the Type A event (18 February) and Type B event (15 May) was the $D_{\mathrm{p}}$ of local maximum $\operatorname{GR}\left(D_{\mathrm{p}}\right)(2.4$ vs. $1.6 \mathrm{~nm})$.

The interesting behaviors of $n\left(D_{\mathrm{p}}\right)$ and GR $\left(D_{\mathrm{p}}\right)$ in our urban atmosphere were different from the stereotyped understanding that steady-state cluster size distribution $n\left(D_{\mathrm{p}}\right)$ decreases with $D_{\mathrm{p}}$ in nucleation and GR increases monotonically with $D_{\mathrm{p}}$ in an NPF event. It should be pointed out that if we calculated the overall GR in $1.4-3 \mathrm{~nm}, \mathrm{GR}_{1.4-3}$ was $3.6 \mathrm{~nm} \mathrm{~h}^{-1}$ on 15 May and $4.4 \mathrm{~nm} \mathrm{~h}^{-1}$ on 18 February, which were still smaller than $\mathrm{GR}_{3-20}$ during the initial period of the events (7.7 and $6.0 \mathrm{~nm} \mathrm{~h}^{-1}$, calculated using appearance-time method). Table 1 showed that a faster $\mathrm{GR}_{3-20}$ than $\mathrm{GR}_{1.4-3}$ were quite common, except in two events on 16 and 20 May when particles did not grow beyond $3 \mathrm{~nm}$. Overall, GR was still increasing with increasing $D_{\mathrm{p}}$.

Kuang et al. (2012) reported a local maximum of GR at $\sim 2.6 \mathrm{~nm}$ in an NPF event measured in Atlanta, USA (Fig. 1b in their paper). In this study we further point out that GR could decrease monotonically with $D_{\mathrm{p}}$ in $1-3 \mathrm{~nm}$ range in strong nucleation events. Our GR was calculated from a simplified GDE method, however, the decease of GR in 1-3 nm size range could be easily inferred from the size spectra shown in the middle panels of Figs. 3 or 6: for a $D_{\mathrm{p} 2}$ that was larger than $D_{\mathrm{p} 1}$, particle formation rate $J\left(D_{\mathrm{p} 2}\right)$ must be smaller than $J\left(D_{\mathrm{p} 1}\right)$. If we observed a higher $n\left(D_{\mathrm{p} 2}\right)$ than $n\left(D_{\mathrm{p} 1}\right), \mathrm{GR}\left(D_{\mathrm{p}}\right)$ that was equal to $J\left(D_{\mathrm{p}}\right) / n\left(D_{\mathrm{p}}\right)$ must be smaller at $D_{\mathrm{p} 2}$ than $D_{\mathrm{p} 1}$.

\subsection{Growth rate due to condensing organic vapor on newly formed nuclei in sub-3 $\mathrm{nm}$ sizes}

Apparently, the complicated growth rate behaviors in our polluted urban atmosphere cannot be explained by $\mathrm{H}_{2} \mathrm{SO}_{4}$ condensation alone, not only because $\mathrm{H}_{2} \mathrm{SO}_{4}$ condensational growth rate $\left(\mathrm{GR}_{\mathrm{H}_{2} \mathrm{SO}_{4}}\right.$, calculated from the $\mathrm{H}_{2} \mathrm{SO}_{4}$ proxy and shown as black dashed lines in Fig. 6) was smaller than the measured growth rate $\left(\mathrm{GR}_{\text {meas }}\right)$, but also because $\mathrm{GR}_{\mathrm{H}_{2} \mathrm{SO}_{4}}$ curve should follow a monotonically decreasing trend in $>1 \mathrm{~nm}$ sizes assuming a collision-only condensational growth without vaporization (Nieminen et al., 2010).

Nano-Köhler theory (Anttila et al., 2004; Kulmala et al., $2004 \mathrm{~b}, \mathrm{c}$ ) suggests that when a soluble organic vapor is dissolved in newly formed nuclei of aqueous-phase sulfate at certain size between 1 and $3 \mathrm{~nm}$, the surface organic vapor pressure is lowered and thus assists the growth of the nuclei. Here, we continued our discussion based on the nanoKöhler theory to provide an explanation of GR behaviours observed in our urban atmosphere. We first subtract $\mathrm{GR}_{\mathrm{H}_{2} \mathrm{SO}_{4}}$ from $\mathrm{GR}_{\text {meas }}$ to obtain the growth rate due to a condensing organic vapor (hereafter, denoted as ELVOC - extremely low volatility organic compound):

$\mathrm{GR}_{\text {meas, elvoc }}=\mathrm{GR}_{\text {meas }}-\mathrm{GR}_{\mathrm{H}_{2} \mathrm{SO}_{4}}$,

where $\mathrm{GR}_{\mathrm{H}_{2} \mathrm{SO}_{4}}$ is calculated from the $\mathrm{H}_{2} \mathrm{SO}_{4}$ proxy concentration $\left[\mathrm{H}_{2} \mathrm{SO}_{4}\right]$ following Nieminen et al. (2010):

$$
\begin{gathered}
\mathrm{GR}_{\mathrm{H}_{2} \mathrm{SO}_{4}}=\frac{\gamma}{2 \rho_{\mathrm{v}, \mathrm{H}_{2} \mathrm{SO}_{4}}}\left(1+\frac{D_{\mathrm{v}, \mathrm{H}_{2} \mathrm{SO}_{4}}}{D_{\mathrm{p}}}\right)^{2}\left(\frac{8 k T}{\pi}\right)^{\frac{1}{2}} \\
\left(\frac{1}{m_{\mathrm{p}}}+\frac{1}{m_{\mathrm{v}, \mathrm{H}_{2} \mathrm{SO}_{4}}}\right)^{\frac{1}{2}} m_{\mathrm{v}, \mathrm{H}_{2} \mathrm{SO}_{4}}\left[\mathrm{H}_{2} \mathrm{SO}_{4}\right]
\end{gathered}
$$

and all parameters in Eq. (4) are taken from Nieminen et al. (2010) for $\mathrm{H}_{2} \mathrm{SO}_{4}$.

The size-dependent growth rate due to the uptake of ELVOC was expressed as 


$$
\begin{gathered}
\mathrm{GR}_{\mathrm{elvoc}}=\frac{\gamma}{2 \rho_{\mathrm{v}, \mathrm{elvoc}}}\left(1+\frac{D_{\mathrm{v}, \mathrm{elv} v \mathrm{c}}}{D_{\mathrm{p}}}\right)^{2}\left(\frac{8 k T}{\pi}\right)^{\frac{1}{2}} \\
\left(\frac{1}{m_{\mathrm{p}}}+\frac{1}{m_{\mathrm{v}, \mathrm{elvoc}}}\right)^{\frac{1}{2}} m_{\mathrm{v}, \text { elvoc }}\left(C_{\text {elvoc }}-C_{\text {surface }}\right),
\end{gathered}
$$

where $C_{\text {elvoc }}$ is gas-phase ELVOC concentration far from the particle. The net uptake of ELVOC is driven by the difference of $C_{\text {elvoc }}$ and equilibrium surface concentration over the particle $C_{\text {surface }} C_{\text {surface }}$ is determined by the pure component saturation vapor pressure $C_{\text {elvoc }}^{*}$, particle curvature $\exp \left(\frac{4 \sigma v}{k T D_{\mathrm{p}}}\right)$ and particle composition:

$C_{\text {surface }}=C_{\text {elvoc }}^{*} \exp \left(\frac{4 \sigma v}{k T D_{\mathrm{p}}}\right) x_{D_{\mathrm{p}}}$.

$x_{D_{\mathrm{p}}}$ is the mole fraction of water-soluble ELVOC in the pseudobinary solution consisting of ELVOC and the aqueous sulfate nuclei. The pseudobinary solution was treated ideal here. An example of $x_{D_{\mathrm{p}}}$ as a function of $D_{\mathrm{p}}$ was shown in Fig. 8a. Nuclei activation diameter $D_{\mathrm{p} \text {,act }}$ is the size that ELVOC fraction begins to increase significantly. For $D_{\mathrm{p}}<D_{\mathrm{p}, \text { act }}, x_{D_{\mathrm{p}}}$ is approximated with a fixed value $\left(x_{0}\right)$. For $D_{\mathrm{p}}>D_{\mathrm{p} \text {,act }}, x_{D_{\mathrm{p}}}$ increases significantly with the organics being added to the sulfate core of $D_{\mathrm{p} \text {, act }}$ size. The sizedependent $x_{D_{\mathrm{p}}}$ is approximated as

$x_{D_{\mathrm{p}}}= \begin{cases}x_{0}, & D_{\mathrm{p}}<D_{\mathrm{p}, \text { act }} \\ x_{0}+\frac{\left(D_{\mathrm{p}}^{3}-D_{\mathrm{p}, \text { act }}^{3}\right) / v_{\mathrm{elvoc}}}{\left(D_{\mathrm{p}}^{3}-D_{\mathrm{p}, \text { act }}^{3} / v_{\mathrm{elv} v \mathrm{c}}+D_{\mathrm{p}, \text { act }}^{3} / v_{\text {sulfate }}\right.}, & D_{\mathrm{p}} \geq D_{\mathrm{p}, \text { act }},\end{cases}$

Considering strong Kelvin effect, $C_{\text {surface }}$ decreases with increasing $D_{\mathrm{p}}$ for $D_{\mathrm{p}}<D_{\mathrm{p} \text {,act }}$ (Fig. $8 \mathrm{~b}$ dashed black line). For $D_{\mathrm{p}}>D_{\mathrm{p} \text {, act }}$, the rapidly increasing organic fraction in the small size regime of $2-3 \mathrm{~nm}$ raises the equilibrium $C_{\text {surface }}$ of ELVOC first. Then for 3-6 nm particles that are dominated by organics, $C_{\text {surface }}$ decreases to merge with the Kelvin curve of a pure organic droplet (red line, Fig. $8 \mathrm{~b}$ ). The complete equilibrium curve of $C_{\text {surface }}$ in 1-6nm (dashed + solid black lines) was shown in Fig. 8c. The blue line represented the calculated $C_{\text {elvoc }}-C_{\text {surface }}$. The trend of $C_{\text {elvoc }}-C_{\text {surface }}$ coincided with the size dependence of the measured GR corrected by $\mathrm{H}_{2} \mathrm{SO}_{4}\left(\mathrm{GR}_{\text {meas,elvoc }}\right.$, Fig. $8 \mathrm{~d}$ blue circle). $D_{\mathrm{p} \text {, act }}$ corresponded to the size with local maximum $\mathrm{GR}_{\text {meas, elvoc. }}$

We fitted $G_{\text {elvoc }}$ with $\mathrm{GR}_{\text {meas,elvoc }}$ in sub- $3 \mathrm{~nm}$ sizes at an instant in time by adjusting three free parameters in Eq. (5): $x_{0}, C_{\text {elvoc }}$, and $C_{\text {elvoc }}^{*}$. Other parameters like surface tension $\left(0.02 \mathrm{Nm}^{-1}\right)$ and molar volume $\left(135.5 \mathrm{~cm}^{3} \mathrm{~mol}^{-1}\right)$ of ELVOC were taken from Kulmala et al. (2004b). Molecule diameter $d_{\mathrm{v}}(0.8 \mathrm{~nm})$ and condensedphase density $\rho_{\mathrm{v}}\left(1.5 \mathrm{~g} \mathrm{~cm}^{-3}\right)$ of ELVOC were taken from Ehn et al. (2014). Uptake coefficient $\gamma$ was calculated following Nieminen et al. (2010). The fitting results in Fig. 9 showed that the dependence of $\mathrm{GR}_{\text {meas, elvoc }}$ on $D_{\mathrm{p}}$ below (a)

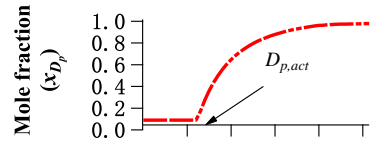

(b)

政

(c)

)
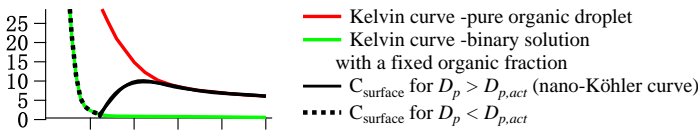

(d)

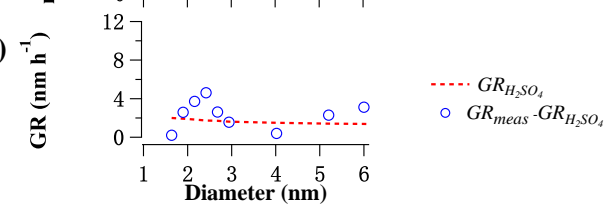

Figure 8. (a) Mole fraction of organics $\left(x_{D_{\mathrm{p}}}\right)$ in a binary solution of sulfate nuclei and activating organics (ELVOC) in a new particle. Nuclei activation diameter $D_{\mathrm{p}}$ act is the size where ELVOC begins to dilute the nuclei. (b) Kelvin equilibrium curves over a pure organic droplet (red line) and a binary solution with a fixed organic fraction (green line), nano-Köhler curve for $D_{\mathrm{p}}>D_{\mathrm{p} \text {, act }}$ (black solid line) and surface concentration $C_{\text {surface }}$ for $D_{\mathrm{p}}<D_{\mathrm{p} \text {, act }}$ (black dashed line). (c) Gas phase concentration of the organic vapor $\left(C_{\text {elvoc}}\right.$, cyan line), surface concentration $C_{\infty}$ (black line), and $C_{\text {elvoc }}-C_{\text {surface }}$ (blue line). (d) Growth rate $\mathrm{GR}_{\mathrm{H}_{2} \mathrm{SO}_{4}}$ due to $\mathrm{H}_{2} \mathrm{SO}_{4}$ (Mikkonen proxy) and growth rate due to organic vapor $\mathrm{GR}_{\text {elvoc, meas }}$, calculated as $\mathrm{GR}_{\text {meas }}-\mathrm{GR}_{\mathrm{H}_{2} \mathrm{SO}_{4}}$.

$3 \mathrm{~nm}$ could be well reproduced by Eq. (5) for both Type A and Type B events. Free parameter $x_{0}$ determined the magnitude of the dashed black line in Fig. 8b. $x_{0}$ was fitted to be $0.07-0.42$ for the eight events. $C_{\infty}$ was sensitive to the local maximum $\mathrm{GR}_{\text {meas,elvoc }}$ at the $D_{\mathrm{p} \text {,act }} C_{\text {elvoc }}$, and $C_{\text {elvoc }}^{*}$ determined the local minimum $\mathrm{GR}_{\text {meas, elvoc }}$ at the right side of $D_{\mathrm{p} \text {,act }}$. Therefore, $C^{*}$ and $C_{\infty}$ were basically determined by the measured GR (local maximum and local minimum) and not sensitive to $x_{0}$. As shown in Table 1, the condensing organic vapor concentrations $C_{\text {elvoc }}$ were $1.7 \times 10^{7}$ $1.7 \times 10^{8} \mathrm{~cm}^{-3}$. The saturation vapor concentrations $C_{\text {elvoc }}^{*}$ were $3.3 \times 10^{6}-5.2 \times 10^{7} \mathrm{~cm}^{-3}$; they were within the orders of magnitude of $10^{7}-10^{8} \mathrm{~cm}^{-3}$ and $10^{6}-10^{7} \mathrm{~cm}^{-3}$ suggested by Kulmala et al. (2004b), respectively.

For comparison, the GR calculated from the appearancetime method was also shown in Fig. 9 (blue cross) for $>3 \mathrm{~nm}$ particles on 15 May, 18 and 19 February, as well as for sub$3 \mathrm{~nm}$ particles on 20 May when particle growth was relatively slow. It can be seen that the GR on 20 May calculated from the two methods agreed well with each other, lending credit to our GDE method. The GR in $>10 \mathrm{~nm}$ sizes was usually underestimated by $\mathrm{GR}_{\text {elvoc}}$. This could be interpreted as other condensing vapors with higher volatility may contribute to particle growth in the larger particles. It should be noted that the appearance-time method followed the time steps when newly formed particles appeared in successive size bins and 

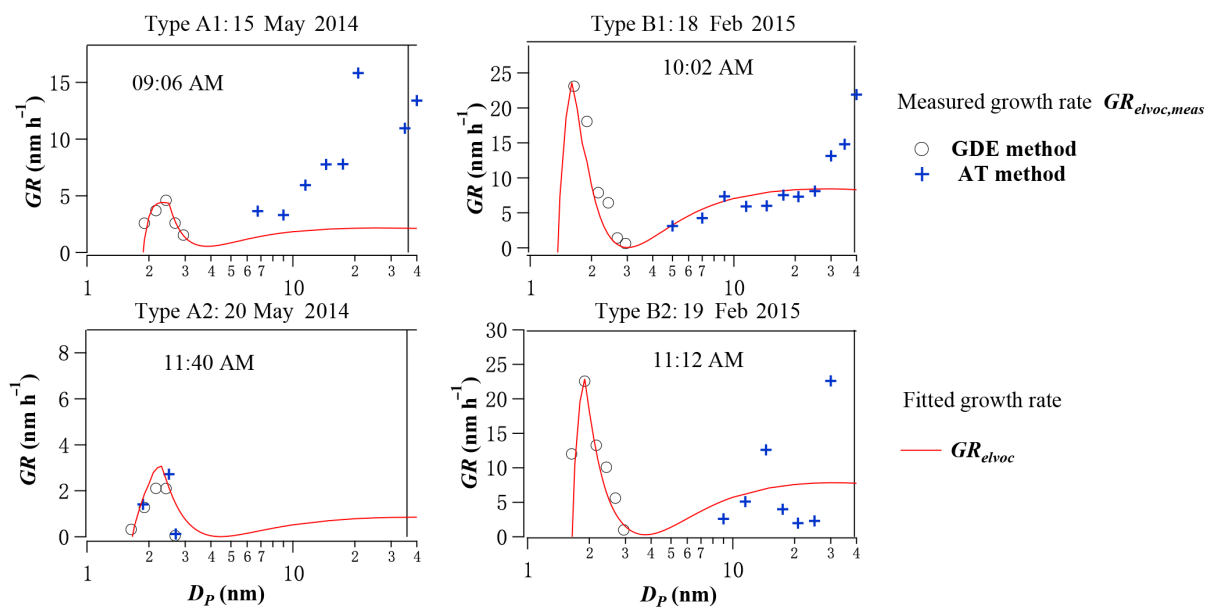

Figure 9. Comparisons of measured $\left(\mathrm{GR}_{\mathrm{elvoc}}\right.$ meas, black circle) and fitted $\left(\mathrm{GR}_{\mathrm{elvoc}}\right.$, red line) growth rates from Eq. (4) for typical Type $\mathrm{A} 1$, A2, B1, and B2 events. Also shown were growth rates calculated from appearance-time method (blue cross) for sub-3 nm particles when growth rate was relatively small or for larger particles with large size intervals.

thus the GR calculated from the appearance-time method as not the growth rates at the same instant in time.

For all the eight nucleation events, Table 1 summarizes the measured values of overall growth rate in $1.4-3 \mathrm{~nm}$ $\left(\mathrm{GR}_{1.4-3}\right)$, maximum growth rate in $1.4-3 \mathrm{~nm}\left(\mathrm{GR}_{\max , 1.4-3}\right)$, overall growth rate in $3-20 \mathrm{~nm}\left(\mathrm{GR}_{3-20}\right)$, nucleation rate $\left(J_{1.4}\right)$, activation diameter $\left(D_{\mathrm{p}, \text { act }}\right), \mathrm{CS}$, and temperature $(T)$ during the event periods with maximum nucleation rates. Corresponding estimates of the Mikkonen $\mathrm{H}_{2} \mathrm{SO}_{4}$ proxy, $C_{\text {elvoc }}$, and $C_{\text {elvoc }}^{*}$ were shown in the right three columns. It can be seen that in comparison with more conventional Type A events, Type B events usually occurred with (1) higher $J_{1.4}, \mathrm{GR}_{\max , 1.4-3}, \mathrm{GR}_{1.4-3}, C_{\text {elvoc }}$, and CS; (2) smaller $D_{\mathrm{p} \text {, act }}$; and (3) lower $T$. However, the $\mathrm{H}_{2} \mathrm{SO}_{4}$ proxy and $\mathrm{GR}_{3-20}$ were similar in Type $\mathrm{A}$ and Type $\mathrm{B}$ events. Based on these estimations, we concluded that higher ELVOC concentration $C_{\text {elvoc }}$ was the key factor leading to the higher $J_{1.4}$ and $\mathrm{GR}_{1.4-3}$, which in turn resulted in the different size spectrum pattern in Type B events ("up-side-down volcano") from in Type A events ("volcano").

It should be noted that the organic vapor concentrations $C_{\text {elvoc }}$ in this study were not directly measured, but estimated based on Eqs. (4) and (5). $C_{\text {elvoc }},\left[\mathrm{H}_{2} \mathrm{SO}_{4}\right]$, mole fraction $x_{D_{\mathrm{p}}}$, and growth rates calculated using Eqs. (4) and (5) were for an instant in time. Aerosol dynamic processes, such as nucleation, coagulation, and the condensation growth of $\mathrm{H}_{2} \mathrm{SO}_{4}$ and water vapor, were not considered explicitly in Eqs. (4) and (5). In addition, bulk thermodynamics was applied in Eq. (5) for extremely small clusters/particles of sub-3 nm sizes. Therefore, although our calculation provided a possibility to explain the size dependence of growth rate observed in the polluted urban atmosphere, $C_{\text {elvoc }}$ in this study was subject to uncertainties in (1) the growth rate derived from the GDE method, (2) the theory by which the growth rate was related to the organic vapor concentration, and (3) $\mathrm{H}_{2} \mathrm{SO}_{4}$ level, which was calculated using Mikkonen proxy.

\subsection{Inhibited particle growth to $\mathrm{CCN}$-active sizes in strong nucleation events of Type B2}

Type B2 was a strong nucleation event that produced rather high concentrations of new particles in sub- $20 \mathrm{~nm}$ size range (Fig. 3d). High concentrations of activating vapor in these events (e.g., $C_{\infty}: 1.4-2.0 \times 10^{8} \mathrm{~cm}^{-3}$ on 18 February and 4 March) should favor a banana-shape NPF event with fast growth of particles $>20 \mathrm{~nm}$, due to weakened Kelvin effect. However, it was puzzling to us why new particles accumulated in 2-20 nm and did not grow further on Type B2 event days (see Fig. 3d). We first examined the air mass trajectory characteristics of Type B2 events. Compared with Type B1, Type B2 was characterized by long-range transport air masses from far north of China and Mongolia. The lumped trajectories with insignificant wind direction change implied that the air mass in Type B2 event was quite uniform. In addition, meteorological and chemical variables (high solar radiation flux and wind speed, low temperature, $\mathrm{PM}_{2.5}$, $\mathrm{SO}_{2}, \mathrm{NO}_{2}, \mathrm{CO}$, and $\mathrm{O}_{3}$; green lines in Fig. 5) collectively suggested that Type B2 was a typical regional event in homogeneous cold air masses. Therefore, the interrupted growth of new particles was not likely to be a result of wind direction change.

As seen from Fig. 5, meteorological variables on Type B2 days were generally more favorable in aiding particle growth than on Type B1 days: lower $\mathrm{PM}_{2.5}$, lower temperature, and higher solar radiation flux. The unfavorable factors in Type B2 events, however, included lower concentrations of $\mathrm{SO}_{2}, \mathrm{NO}_{2}$, and $\mathrm{CO}$ (anthropogenic emission indicators), lower secondary photochemical product indicators $\mathrm{O}_{3}$ and lower particle phase sulfate in 100-1000 nm (X. Ge, personal 
communication, 2015; X. Ge conducted simultaneous AMS measurement during our measurement periods). All of these evidences suggested that further particle growth in Type B2 events was limited by certain condensing vapor other than ELVOC. Consequently, although there was a pool of sub$20 \mathrm{~nm}$ particles, they were not further "activated" due to the low availability of this condensing vapor. Following the terminology of Donahue et al. $(2011,2012)$, we called this condensing vapor LVOC (low volatility organic compounds).

The above hypothesis was sound if we considered that the identity of LVOC for the growth of particles $>20 \mathrm{~nm}$ could be different from ELVOC for sub- $3 \mathrm{~nm}$ particle growth. Hirsikko et al. (2005) observed that $\mathrm{GR}_{3-20}$ demonstrated an opposite seasonal cycle to $\mathrm{GR}_{1.3-3}$ : $\mathrm{GR}_{3-20}$ was higher in summer, whereas $\mathrm{GR}_{1.3-3}$ was higher in winter. This suggested that the condensing vapors were different in identity for particles of different sizes. Hirsikko et al. (2005) attributed the condensing vapors for $\mathrm{GR}_{3-20}$ to biogenetic VOCs. In our urban atmosphere, according to Fig. 5, LVOC was more likely to be from anthropogenic sources associated with $\mathrm{SO}_{2}, \mathrm{NO}_{x}$, and $\mathrm{CO}$ emissions. A picture of the growth process was thus like this: ELVOC of lower volatility, lower concentration, and higher water solubility activated inorganic nuclei and accelerated particle growth in smaller sizes. This in turn assisted in the condensation of LVOC of high volatility, low solubility, but with larger amount of mass. The further growth of particles $>20 \mathrm{~nm}$, which means significant increment of particle mass, needed continuous supply of LVOC from the anthropogenic sources. On the Type B2 days, LVOC supply was not adequate (low $\mathrm{SO}_{2}, \mathrm{CO}$ and $\mathrm{NO}_{x}$ ). As a result, continuous banana-shape particle growth did not take place.

\subsection{Comparison with two other sub- $3 \mathrm{~nm}$ particle studies in the YRD megacities}

Herrmann et al. (2014), Xiao et al. (2015), and this study investigated sub- $3 \mathrm{~nm}$ particle occurrences in the polluted megacities (Nanjing and Shanghai) of the YRD region. Our study had three advantages over previous studies: (1) we derived time- and size-resolved nucleation rate and growth rate, and thus provide more information about NPF, (2) we decoupled the nucleation and growth processes by differentiating sub-3 $\mathrm{nm}$ particle events from conventional NPF events. This allowed us to investigate the controlling factors in the two processes respectively, (3) our measurement period covered spring, summer, and winter seasons, and thus wider ranges of environmental condition variables. Here we compared the results from the three studies. The objective was to investigate how these independent studies contribute collectively to the understanding of NPF in the YRD megacities.

First, we compared the NPF frequency, nucleation rate, and growth rate. All three studies detected NPF events on about $20 \%$ of winter observation days. Including summer and spring with fewer events, we observed the overall NPF frequency was $10 \%$ in Nanjing. Using sub-3 nm particle event as an approximate measure of nucleation, we found nucleation frequency actually much higher $(47 \%$ of all observation days). Xiao et al. (2015) observed that average $J_{1.34}$ at the onset of winter nucleation events was $188 \mathrm{~cm}^{-3} \mathrm{~s}^{-1}$ in Shanghai. Using a different GDE method, we found that the event-averaged $J_{1.4}$ ranged from 20 to $500 \mathrm{~cm}^{-3} \mathrm{~s}^{-1}$ in the eight events. Clear diurnal variations of $J_{1.4}$ was observed with peak values up to $2500 \mathrm{~cm}^{-3} \mathrm{~s}^{-1}$. In the size range of 3$30 \mathrm{~nm}$, GR was quite close in all three studies, ranging from $4.5-11 \mathrm{~nm} \mathrm{~h}^{-1}$. In the sub-3 nm size range, however, our median $\mathrm{GR}_{1.4-3}$ was $4.3 \mathrm{~nm} \mathrm{~h}^{-1}$, which was higher than median $\mathrm{GR}_{1.35-2.39}$ of $0.94 \mathrm{~nm} \mathrm{~h}^{-1}$ observed in Shanghai.

From these comparisons we concluded that (1) nucleation rate in the polluted YRD urban area was clearly higher than those typically observed in most remote or moderately polluted environments (Jiang et al., 2011b; Kuang et al., 2012; Kulmala et al., 2013; Lehtipalo et al., 2009, 2010, 2011; Yu et al., 2014a, b); (2) our results showed a wider range of nucleation rate (a few to $2.5 \times 10^{3} \mathrm{~cm}^{-3} \mathrm{~s}^{-1}$ ) than Xiao et al. (2015) and Herrmann et al. (2014), not only because our data covered 3 seasons, but also because our time-resolved $J$ included the entire nucleation period. (3) GR in the sub- $3 \mathrm{~nm}$ size range was higher in our study than in Shanghai, partly because the GDE method allowed one to determine higher GR than the appearance-time method.

Second, we compared the NPF mechanisms in this polluted area reported by the three studies. Based on winter data only, Herrmann et al. (2014) did not find any correlation between temperature and nucleation in Nanjing. But if combining data from different seasons, we found significant negative correlation between $J_{1.4}$ and temperature (Fig. 7b), implying atmospheric nucleation was not favored under high temperature conditions. Herrmann et al. (2014) suggested $\mathrm{SO}_{2}$ was excessive for the winter NPF in Nanjing. We further pointed out that $\mathrm{SO}_{2}$ may not be excessive in summer and is an unfavorable factor of rare summer nucleation event. Based only on winter observations, Herrmann et al. (2014) and Xiao et al. (2015) identified radiation or $\mathrm{H}_{2} \mathrm{SO}_{4}$ as the main driving force of NPF and CS as the main obstacle. While we recognized this, we concluded that other environmental variables like temperature and $\mathrm{RH}$ can also control the occurrence of atmospheric nucleation under various atmospheric conditions. Furthermore, for the subsequent growth of sub- $3 \mathrm{~nm}$ particles to $\mathrm{CCN}$-active sizes, the supply of anthropogenic gaseous precursors other that $\mathrm{H}_{2} \mathrm{SO}_{4}$ can also become a limiting factor.

Last, all the three studies tried to correlate Mikkonen's $\mathrm{H}_{2} \mathrm{SO}_{4}$ proxy to nucleation rate or growth rate. Only our study produced a significant correlation between $J$ and $\left[\mathrm{H}_{2} \mathrm{SO}_{4}\right]^{n}\left(R^{2}=0.56-0.86\right)$ with $n=0.82-1.2$ (Fig. 7a). The better correlation was mainly because we used hourly $J$ and $\left[\mathrm{H}_{2} \mathrm{SO}_{4}\right]$ data, whereas the other two studies had fewer data points, i.e., one $J$ value for each event. Xiao et al. (2015) proposed that the $\mathrm{H}_{2} \mathrm{SO}_{4}$ proxy was sufficient to explain their observed $\mathrm{GR}_{1.34-3}$. In contrast, our study suggested that other 
condensing vapors were needed to explain GR in both sub$3 \mathrm{~nm}$ and $>3 \mathrm{~nm}$ size ranges.

\section{Conclusion}

NPF can contribute to CCN only after going through nucleation, initial growth steps, and subsequent growth to $\mathrm{CCN}$ active sizes. This study provided the evidences of limiting factors in these processes in a polluted urban atmosphere in China. We observed atmospheric nucleation events on 42 out of total 90 observation days, but particles could grow to $\mathrm{CCN}$-active sizes on only 9 days, which was equivalent to nine conventional NPF events. In summer, strict emission control measures during the 2014 Youth Olympic Games resulted in relatively low $\mathrm{PM}_{2.5}$ and anthropogenic trace gases $\left(\mathrm{SO}_{2}, \mathrm{NO}_{2}, \mathrm{CO}\right.$, and $\left.\mathrm{O}_{3}\right)$ levels. Infrequent nucleation was thus limited by both low concentrations of gaseous precursors and high temperature and RH in summer. In more polluted winter and spring atmosphere, precursor supply was not limiting anymore; nucleation occurred once meteorological conditions were favorable (i.e. low CS and temperature/RH, higher solar radiation). However, for the further growth of sub- $3 \mathrm{~nm}$ particles to $\mathrm{CCN}$-active sizes, anthropogenic gaseous precursors again became limiting factors.

A simplified GDE method was used in this study to calculate particle formation rates first and then growth rates. Nucleation events were strong in the polluted urban atmosphere of Nanjing. Initial $J_{1.4}$ at the onset and peak $J_{1.4}$ at the noontime could be up to $2.1 \times 10^{2}$ and $2.5 \times 10^{3} \mathrm{~cm}^{-3} \mathrm{~s}^{-1}$, respectively, during the eight nucleation events selected from different seasons. The diurnal variation of $J_{1.4}$ implied that nucleation was usually linked to sunlight induced photochemistry. Time-dependent $J_{1.4}$ showed good linear correlations with the $\mathrm{H}_{2} \mathrm{SO}_{4}$ proxy for every single event, except a day with significant nocturnal nucleation. However, the correlation between $J_{1.4}$ and the $\mathrm{H}_{2} \mathrm{SO}_{4}$ proxy for all eight events deteriorated, which might reflect the effect of temperature or assisting vapor concentration in the nucleation. The deteriorated correlation could also be due to the lower predictive ability of the $\mathrm{H}_{2} \mathrm{SO}_{4}$ proxy in the polluted urban atmosphere for different seasons.

In all nucleation events, a local maximum growth rate was observed between 1 and $3 \mathrm{~nm}$ with GR up to $25 \mathrm{~nm} \mathrm{~h}^{-1}$. This means GR was not monotonically increasing with particle size. The overall $\mathrm{GR}_{1.4-3}$, however, was still smaller than $\mathrm{GR}_{3-20}$, if particles could grow beyond $3 \mathrm{~nm}$. However, it should be noted that the existence of local maxima GR in sub- $3 \mathrm{~nm}$ is highly sensitive to the uncertainty of size distribution derivation, i.e. the moving average filter was used to smooth original noisy raw data of $N_{1.5}, N_{1.8}$, $N_{2.0}, N_{2.3}, N_{2.6}$, and $N_{2.8}$. The noise is due to the nature of sub- $3 \mathrm{~nm}$ cluster dynamics, environmental conditions, and instrumental uncertainties. On the other hand, the GR observation is potentially real and might give new insight into clus- ter dynamics in polluted environments. The local maximum growth rate was interpreted as the solvation effect of organic activating vapor in newly formed inorganic nuclei. Based on our estimation, high ELVOC concentration of $2.3 \times 10^{7}$ $2.0 \times 10^{8} \mathrm{~cm}^{-3}$ was expected to be the key factor leading to high $\mathrm{GR}_{1.4-3}$. The varying GR of new particles in turn resulted in the different particle growth patterns that we observed in Nanjing.

Our results call for a more robust proxy of gaseous $\mathrm{H}_{2} \mathrm{SO}_{4}$ to be developed for polluted urban conditions. The study also highlighted the importance of estimating or measuring activating organic vapor levels (using CI-APi-TOF, for example) in the initial growth steps of atmospheric NPF. Our year-round measurement data provided valuable size evolution data of sub- $3 \mathrm{~nm}$ clusters/particles to evaluate previous aerosol dynamic models of new particle formation. A robust dynamic model was needed to appropriately treat all aerosol and gas-phase processes in the initial growth steps.

Acknowledgements. This work was supported by National Science Foundation of China (grant nos. 41405116, 21577065 and 91543115), Natural Science Foundation of Jiangsu Province (grant no. BK20140989), and Jiangsu Specially Appointed Professor grant and International ST Cooperation Program of China (2014DFA90780). The measurement campaigns were partially funded by the Priority Academic Program Development of Jiangsu Higher Education Institutions (PAPD). J. Zheng acknowledges funding support from NSFC 41275142 and 41575122 . We thank Vijay P. Kanawade and Xinlei Ge for valuable discussions. The comments from the editor helped us to improve the manuscript and are highly appreciated by the authors.

Edited by: M. Kulmala

\section{References}

Almeida, J., Schobesberger, S., Kurten, A., Ortega, I. K., Kupiainen-Maatta, O., Praplan, A. P., Adamov, A., Amorim, A., Bianchi, F., Breitenlechner, M., David, A., Dommen, J., Donahue, N. M., Downard, A., Dunne, E., Duplissy, J., Ehrhart, S., Flagan, R. C., Franchin, A., Guida, R., Hakala, J., Hansel, A., Heinritzi, M., Henschel, H., Jokinen, T., Junninen, H., Kajos, M., Kangasluoma, J., Keskinen, H., Kupc, A., Kurten, T., Kvashin, A. N., Laaksonen, A., Lehtipalo, K., Leiminger, M., Leppa, J., Loukonen, V., Makhmutov, V., Mathot, S., McGrath, M. J., Nieminen, T., Olenius, T., Onnela, A., Petaja, T., Riccobono, F., Riipinen, I., Rissanen, M., Rondo, L., Ruuskanen, T., Santos, F. D., Sarnela, N., Schallhart, S., Schnitzhofer, R., Seinfeld, J. H., Simon, M., Sipila, M., Stozhkov, Y., Stratmann, F., Tome, A., Trostl, J., Tsagkogeorgas, G., Vaattovaara, P., Viisanen, Y., Virtanen, A., Vrtala, A., Wagner, P. E., Weingartner, E., Wex, H., Williamson, C., Wimmer, D., Ye, P., Yli-Juuti, T., Carslaw, K. S., Kulmala, M., Curtius, J., Baltensperger, U., Worsnop, D. R., Vehkamaki, H., and Kirkby, J.: Molecular understanding of sulphuric acid-amine particle nucleation in the atmosphere, Nature, 502, 359-363, doi:10.1038/nature12663, 2013. 
Anttila, T., Kerminen, V.-M., Kulmala, M., Laaksonen, A., and O'Dowd, C. D.: Modelling the formation of organic particles in the atmosphere, Atmos. Chem. Phys., 4, 1071-1083, doi:10.5194/acp-4-1071-2004, 2004.

Asmi, E., Sipilä, M., Manninen, H. E., Vanhanen, J., Lehtipalo, K., Gagné, S., Neitola, K., Mirme, A., Mirme, S., Tamm, E., Uin, J., Komsaare, K., Attoui, M., and Kulmala, M.: Results of the first air ion spectrometer calibration and intercomparison workshop, Atmos. Chem. Phys., 9, 141-154, doi:10.5194/acp-9-141-2009, 2009.

Brus, D., Neitola, K., Hyvärinen, A.-P., Petäjä, T., Vanhanen, J., Sipilä, M., Paasonen, P., Kulmala, M., and Lihavainen, H.: Homogenous nucleation of sulfuric acid and water at close to atmospherically relevant conditions, Atmos. Chem. Phys., 11, 52775287, doi:10.5194/acp-11-5277-2011, 2011.

Chan, C. K. and Yao, X.: Air pollution in mega cities in China, Atmos. Environ., 42, 1-42, doi:10.1016/j.atmosenv.2007.09.003, 2008.

Donahue, N. M., Trump, E. R., Pierce, J. R., and Riipinen, I.: Theoretical constraints on pure vapor-pressure driven condensation of organics to ultrafine particles, Geophys. Res. Lett., 38, L16801, doi:10.1029/2011g1048115, 2011.

Donahue, N. M., Kroll, J. H., Pandis, S. N., and Robinson, A. L.: A two-dimensional volatility basis set - Part 2: Diagnostics of organic-aerosol evolution, Atmos. Chem. Phys., 12, 615-634, doi:10.5194/acp-12-615-2012, 2012.

Ehn, M., Thornton, J. A., Kleist, E., Sipila, M., Junninen, H., Pullinen, I., Springer, M., Rubach, F., Tillmann, R., Lee, B., LopezHilfiker, F., Andres, S., Acir, I.-H., Rissanen, M., Jokinen, T., Schobesberger, S., Kangasluoma, J., Kontkanen, J., Nieminen, T., Kurten, T., Nielsen, L. B., Jorgensen, S., Kjaergaard, H. G., Canagaratna, M., Maso, M. D., Berndt, T., Petaja, T., Wahner, A., Kerminen, V. M., Kulmala, M., Worsnop, D. R., Wildt, J., and Mentel, T. F.: A large source of low-volatility secondary organic aerosol, Nature, 506, 476-479, doi:10.1038/nature13032, 2014.

Herrmann, E., Ding, A. J., Kerminen, V.-M., Petäjä, T., Yang, X. Q., Sun, J. N., Qi, X. M., Manninen, H., Hakala, J., Nieminen, T., Aalto, P. P., Kulmala, M., and Fu, C. B.: Aerosols and nucleation in eastern China: first insights from the new SORPES-NJU station, Atmos. Chem. Phys., 14, 2169-2183, doi:10.5194/acp14-2169-2014, 2014.

Hirsikko, A., Laakso, L., Horrak, U., Aalto, P. P., Kerminen, V. M., and Kulmala, M.: Annual and size dependent variation of growth rates and ion concentrations in boreal forest, Boreal Environ. Res., 10, 357-469, 2005.

Jiang, J., Chen, M., Kuang, C., Attoui, M., and McMurry, P. H.: Electrical Mobility Spectrometer Using a Diethylene Glycol Condensation Particle Counter for Measurement of Aerosol Size Distributions Down to $1 \mathrm{~nm}$, Aerosol Sci. Tech., 45, 510-521, doi:10.1080/02786826.2010.547538, 2011a.

Jiang, J., Zhao, J., Chen, M., Eisele, F. L., Scheckman, J., Williams, B. J., Kuang, C., and McMurry, P. H.: First Measurements of Neutral Atmospheric Cluster and 1-2 nm Particle Number Size Distributions During Nucleation Events, Aerosol Sci. Tech., 45, II-V, doi:10.1080/02786826.2010.546817, 2011b.

Jokinen, T., Sipilä, M., Junninen, H., Ehn, M., Lönn, G., Hakala, J., Petäjä, T., Mauldin III, R. L., Kulmala, M., and Worsnop, D. R.: Atmospheric sulphuric acid and neutral cluster measure- ments using CI-APi-TOF, Atmos. Chem. Phys., 12, 4117-4125, doi:10.5194/acp-12-4117-2012, 2012.

Junninen, H., Hulkkonen, M., Riipinen, I., Nieminen, T., Hirsikko, A., Suni, T., Boy, M., Lee, S.-H., Vana, M., Tammet, T., Kerminen, V. M., and Kulmala, M.: Observations on nocturnal growth of atmospheric clusters, Tellus B, 60, 365-371, doi:10.1111/j.1600-0889.2008.00356.x, 2008.

Junninen, H., Ehn, M., Petäjä, T., Luosujärvi, L., Kotiaho, T., Kostiainen, R., Rohner, U., Gonin, M., Fuhrer, K., Kulmala, M., and Worsnop, D. R.: A high-resolution mass spectrometer to measure atmospheric ion composition, Atmos. Meas. Tech., 3, 10391053, doi:10.5194/amt-3-1039-2010, 2010.

Kangasluoma, J., Kuang, C., Wimmer, D., Rissanen, M. P., Lehtipalo, K., Ehn, M., Worsnop, D. R., Wang, J., Kulmala, M., and Petäjä, T.: Sub-3 nm particle size and composition dependent response of a nano-CPC battery, Atmos. Meas. Tech., 7, 689-700, doi:10.5194/amt-7-689-2014, 2014.

Kirkby, J., Curtius, J., Almeida, J., Dunne, E., Duplissy, J., Ehrhart, S., Franchin, A., Gagne, S., Ickes, L., Kurten, A., Kupc, A., Metzger, A., Riccobono, F., Rondo, L., Schobesberger, S., Tsagkogeorgas, G., Wimmer, D., Amorim, A., Bianchi, F., Breitenlechner, M., David, A., Dommen, J., Downard, A., Ehn, M., Flagan, R. C., Haider, S., Hansel, A., Hauser, D., Jud, W., Junninen, H., Kreissl, F., Kvashin, A., Laaksonen, A., Lehtipalo, K., Lima, J., Lovejoy, E. R., Makhmutov, V., Mathot, S., Mikkila, J., Minginette, P., Mogo, S., Nieminen, T., Onnela, A., Pereira, P., Petaja, T., Schnitzhofer, R., Seinfeld, J. H., Sipila, M., Stozhkov, Y., Stratmann, F., Tome, A., Vanhanen, J., Viisanen, Y., Vrtala, A., Wagner, P. E., Walther, H., Weingartner, E., Wex, H., Winkler, P. M., Carslaw, K. S., Worsnop, D. R., Baltensperger, U., and Kulmala, M.: Role of sulphuric acid, ammonia and galactic cosmic rays in atmospheric aerosol nucleation, Nature, 476, 429-433, doi:10.1038/nature10343, 2011.

Kuang, C., Chen, M., Zhao, J., Smith, J., McMurry, P. H., and Wang, J.: Size and time-resolved growth rate measurements of 1 to $5 \mathrm{~nm}$ freshly formed atmospheric nuclei, Atmos. Chem. Phys., 12, 3573-3589, doi:10.5194/acp-12-3573-2012, 2012.

Kulmala, M., Pirjola, L., and Makela, J. M.: Stable sulfate clusters as a source of new atmospheric particles, Nature, 404, 60-66, doi:10.1038/35003550, 2000.

Kulmala, M., Laakso, L., Lehtinen, K. E. J., Riipinen, I., Dal Maso, M., Lauria, A., Kerminen, V. M., Birmili, W., and McMurry, P. H.: Formation and growth rates of ultrafine atmosphere particles: A review of observations, J. Aerosol. Sci., 35, 143-176, 2004a.

Kulmala, M., Kerminen, V. M., Anntila, T., Laaksonen, A., and O'Dowd, C. D.: Organic aerosol formation via sulfate cluster activation, J. Geophys. Res., 109, D04205, doi:10.1029/2003JD003961, 2004b.

Kulmala, M., Laakso, L., Lehtinen, K. E. J., Riipinen, I., Dal Maso, M., Anttila, T., Kerminen, V.-M., Hõrrak, U., Vana, M., and Tammet, H.: Initial steps of aerosol growth, Atmos. Chem. Phys., 4, 2553-2560, doi:10.5194/acp-4-2553-2004, 2004c.

Kulmala, M., Petäjä, T., Nieminen, T., Sipilä, M., Manninen, H. E., Lehtipalo, K., Dal Maso, M., Aalto, P. P., Junninen, H., Paasonen, P., Riipinen, I., Lehtinen, K. E. J., Laaksonen, A., and Kerminen, V. M.: Measurement of the nucleation of atmospheric aerosol particles, Nat. Protoc., 7, 1651-1667, doi:10.1038/nprot.2012.091, 2012. 
Kulmala, M., Kontkanen, J., Junninen, H., Lehtipalo, K., Manninen, H. E., Nieminen, T., Petäjä, T., Sipilä, M., Schobesberger, S., Rantala, P., Franchin, A., Jokinen, T., Järvinen, E., Äijälä, M., Kangasluoma, J., Hakala, J., Aalto, P. P., Paasonen, P., Mikkilä, J., Vanhanen, J., Aalto, J., Hakola, H., Makkonen, U., Ruuskanen, T., Mauldin, R. L., Duplissy, J., Vehkamäki, H., Bäck, J., Kortelainen, A., Riipinen, I., Kurtén, T., Johnston, M. V., Smith, J. N., Ehn, M., Mentel, T. F., Lehtinen, K. E. J., Laaksonen, A., Kerminen, V. M., and Worsnop, D. R.: Direct Observations of Atmospheric Aerosol Nucleation, Science, 339, $943-$ 946, doi:10.1126/science.1227385, 2013.

Kulmala, M., Petäjä, T., Ehn, M., Thornton, J., Sipilä, M., Worsnop, D. R., and Kerminen, V. M.: Chemistry of Atmospheric Nucleation: On the Recent Advances on Precursor Characterization and Atmospheric Cluster Composition in Connection with Atmospheric New Particle Formation, Annu. Rev. Phys. Chem., 65, 21-37, doi:10.1146/annurev-physchem-040412-110014, 2014.

Kürten, A., Jokinen, T., Simon, M., Sipilä, M., Sarnela, N., Junninen, H., Adamov, A., Almeida, J., Amorim, A., Bianchi, F., Breitenlechner, M., Dommen, J., Donahue, N. M., Duplissy, J., Ehrhart, S., Flagan, R. C., Franchin, A., Hakala, J., Hansel, A., Heinritzi, M., Hutterli, M., Kangasluoma, J., Kirkby, J., Laaksonen, A., Lehtipalo, K., Leiminger, M., Makhmutov, V., Mathot, S., Onnela, A., Petäjä, T., Praplan, A. P., Riccobono, F., Rissanen, M. P., Rondo, L., Schobesberger, S., Seinfeld, J. H., Steiner, G., Tomé, A., Tröstl, J., Winkler, P. M., Williamson, C., Wimmer, D., Ye, P., Baltensperger, U., Carslaw, K. S., Kulmala, M., Worsnop, D. R., and Curtius, J.: Neutral molecular cluster formation of sulfuric acid-dimethylamine observed in real time under atmospheric conditions, P. Natl. Acad. Sci. USA, 111, 1501915024, doi:10.1073/pnas.1404853111, 2014.

Lee, S. H., Young, L. H., Benson, D. R., Kulmala, M., Junninen, H., Suni, T., Campos, T., Rogers, D. C., and Jensen, J.: Observations of nighttime new particle formation in the troposphere, $\mathrm{J}$. Geophys. Res., 113, D10210, doi:10.1029/2007JD009351, 2008.

Lehtipalo, K., Sipilä, M., Riipinen, I., Nieminen, T., and Kulmala, M.: Analysis of atmospheric neutral and charged molecular clusters in boreal forest using pulse-height CPC, Atmos. Chem. Phys., 9, 4177-4184, doi:10.5194/acp-9-4177-2009, 2009.

Lehtipalo, K., Kulmala, M., Sipilä, M., Petäjä, T., Vana, M., Ceburnis, D., Dupuy, R., and O'Dowd, C.: Nanoparticles in boreal forest and coastal environment: a comparison of observations and implications of the nucleation mechanism, Atmos. Chem. Phys., 10, 7009-7016, doi:10.5194/acp-10-7009-2010, 2010.

Lehtipalo, K., Sipila, M., Junninen, H., Ehn, M., Berndt, T., Kajos, M. K., Worsnop, D. R., Petaja, T., and Kulmala, M.: Observations of Nano-CN in the Nocturnal Boreal Forest, Aerosol Sci. Tech., 45, 499-509, doi:10.1080/02786826.2010.547537, 2011.

Lehtipalo, K., Leppä, J., Kontkanen, J., Kangasluoma, J., Franchin, A., Wimmer, D., Schobesberger, S., Junninen, H., Petäjä, T., Sipilä, M., Mikkilä, J., Vanhanen, J., Worsnop, D. R., and Kulmala, M.: Methods for determining particle size distribution and growth rates between 1 and $3 \mathrm{~nm}$ using the Particle Size Magnifier, Boreal Environ. Res., 19, 215-236, 2014.

Matsui, H., Koike, M., Takegawa, N., Kondo, Y., Takami, A., Takamura, T., Yoon, S., Kim, S. W., Lim, H. C., and Fast, J. D.: Spatial and temporal variations of new particle formation in East Asia using an NPF-explicit WRF-chem model: North-south con- trast in new particle formation frequency, J. Geophys. Res., 118, 11647-11663, doi:10.1002/jgrd.50821, 2013.

Merikanto, J., Spracklen, D. V., Mann, G. W., Pickering, S. J., and Carslaw, K. S.: Impact of nucleation on global CCN, Atmos. Chem. Phys., 9, 8601-8616, doi:10.5194/acp-9-8601-2009, 2009.

Mikkonen, S., Romakkaniemi, S., Smith, J. N., Korhonen, H., Petäjä, T., Plass-Duelmer, C., Boy, M., McMurry, P. H., Lehtinen, K. E. J., Joutsensaari, J., Hamed, A., Mauldin III, R. L., Birmili, W., Spindler, G., Arnold, F., Kulmala, M., and Laaksonen, A.: A statistical proxy for sulphuric acid concentration, Atmos. Chem. Phys., 11, 11319-11334, doi:10.5194/acp-11-11319-2011, 2011.

Nieminen, T., Lehtinen, K. E. J., and Kulmala, M.: Sub-10 nm particle growth by vapor condensation - effects of vapor molecule size and particle thermal speed, Atmos. Chem. Phys., 10, $9773-$ 9779, doi:10.5194/acp-10-9773-2010, 2010.

Ortega, I. K., Suni, T., Gronholm, T., Boy, M., Hakola, H., Hellen, H., Valmari, T., Arvela, H., Vehkamaki, H., and Kulmala, M.: Is eucalyptol the cause of nocturnal events observed in Australia?, Boreal Environ. Res., 14, 606-615, 2009.

Ortega, I. K., Suni, T., Boy, M., Grönholm, T., Manninen, H. E., Nieminen, T., Ehn, M., Junninen, H., Hakola, H., Hellén, H., Valmari, T., Arvela, H., Zegelin, S., Hughes, D., Kitchen, M., Cleugh, H., Worsnop, D. R., Kulmala, M., and Kerminen, V.-M.: New insights into nocturnal nucleation, Atmos. Chem. Phys., 12, 4297-4312, doi:10.5194/acp-12-4297-2012, 2012.

Petäjä, T., Mauldin, III, R. L., Kosciuch, E., McGrath, J., Nieminen, T., Paasonen, P., Boy, M., Adamov, A., Kotiaho, T., and Kulmala, M.: Sulfuric acid and $\mathrm{OH}$ concentrations in a boreal forest site, Atmos. Chem. Phys., 9, 7435-7448, doi:10.5194/acp9-7435-2009, 2009.

Pierce, J. R. and Adams, P. J.: Uncertainty in global CCN concentrations from uncertain aerosol nucleation and primary emission rates, Atmos. Chem. Phys., 9, 1339-1356, doi:10.5194/acp-91339-2009, 2009.

Riccobono, F., Schobesberger, S., Scott, C. E., Dommen, J., Ortega, I. K., Rondo, L., Almeida, J., Amorim, A., Bianchi, F., Breitenlechner, M., David, A., Downard, A., Dunne, E. M., Duplissy, J., Ehrhart, S., Flagan, R. C., Franchin, A., Hansel, A., Junninen, H., Kajos, M., Keskinen, H., Kupc, A., Kürten, A., Kvashin, A. N., Laaksonen, A., Lehtipalo, K., Makhmutov, V., Mathot, S., Nieminen, T., Onnela, A., Petäjä, T., Praplan, A. P., Santos, F. D., Schallhart, S., Seinfeld, J. H., Sipilä, M., Spracklen, D. V., Stozhkov, Y., Stratmann, F., Tomé, A., Tsagkogeorgas, G., Vaattovaara, P., Viisanen, Y., Vrtala, A., Wagner, P. E., Weingartner, E., Wex, H., Wimmer, D., Carslaw, K. S., Curtius, J., Donahue, N. M., Kirkby, J., Kulmala, M., Worsnop, D. R., and Baltensperger, U.: Oxidation Products of Biogenic Emissions Contribute to Nucleation of Atmospheric Particles, Science, 344, 717-721, doi:10.1126/science.1243527, 2014.

Riipinen, I., Yli-Juuti, T., Pierce, J. R., Petaja, T., Worsnop, D. R., Kulmala, M., and Donahue, N. M.: The contribution of organics to atmospheric nanoparticle growth, Nat. Geosci., 5, 453-458, doi:10.1038/NGEO1499, 2012.

Russell, L. M., Mensah, A. A., Fischer, E. V., Sive, B. C., Varner, R. K., Keene, W. C., Stutz, J., and Pszenny, A. A. P.: Nanoparticle growth following photochemical $\alpha$ - and $\beta$-pinene oxidation at Appledore Island during International Consortium for Research on Transport and Transformation/Chemistry of Halo- 
gens at the Isles of Shoals 2004, J. Geophys. Res., 112, D10S21, doi:10.1029/2006jd007736, 2007.

Schobesberger, S., Junninen, H., Bianchi, F., Lönn, G., Ehn, M., Lehtipalo, K., Dommen, J., Ehrhart, S., Ortega, I. K., Franchin, A., Nieminen, T., Riccobono, F., Hutterli, M., Duplissy, J., Almeida, J., Amorim, A., Breitenlechner, M., Downard, A. J., Dunne, E. M., Flagan, R. C., Kajos, M., Keskinen, H., Kirkby, J., Kupc, A., Kürten, A., Kurtén, T., Laaksonen, A., Mathot, S., Onnela, A., Praplan, A. P., Rondo, L., Santos, F. D., Schallhart, S., Schnitzhofer, R., Sipilä, M., Tomé, A., Tsagkogeorgas, G., Vehkamäki, H., Wimmer, D., Baltensperger, U., Carslaw, K. S., Curtius, J., Hansel, A., Petäjä, T., Kulmala, M., Donahue, N. M., and Worsnop, D. R.: Molecular understanding of atmospheric particle formation from sulfuric acid and large oxidized organic molecules, P. Natl. Acad. Sci. USA, 110, 17223-17228, doi:10.1073/pnas.1306973110, 2013.

Sipila, M., Lehtipalo, K., Attoui, M., Neitola, K., Petäjä, T., Aalto, P. P., O'Dowd, C. D., and Kulmala, M.: Laboratory Verification of PH-CPC's Ability to Monitor Atmospheric Sub-3 nm Clusters, Aerosol Sci. Tech., 43, 126-135, doi:10.1080/02786820802506227, 2009.

Spracklen, D. V., Carslaw, K. S., Kulmala, M., Kerminen, V.-M., Sihto, S.-L., Riipinen, I., Merikanto, J., Mann, G. W., Chipperfield, M. P., Wiedensohler, A., Birmili, W., and Lihavainen, H.: Contribution of particle formation to global cloud condensation nuclei concentrations, Geophys. Res. Lett., 35, L06808, doi:10.1029/2007GL033038, 2008.

Suni, T., Kulmala, M., Hirsikko, A., Bergman, T., Laakso, L., Aalto, P. P., Leuning, R., Cleugh, H., Zegelin, S., Hughes, D., van Gorsel, E., Kitchen, M., Vana, M., Hõrrak, U., Mirme, S., Mirme, A., Sevanto, S., Twining, J., and Tadros, C.: Formation and characteristics of ions and charged aerosol particles in a native Australian Eucalypt forest, Atmos. Chem. Phys., 8, 129-139, doi:10.5194/acp-8-129-2008, 2008.

Svenningsson, B., Arneth, A., Hayward, S., Holst, T., Massling, A., Swietlicko, E., Hirsikko, A., Junninen, H., Riipinen, I., Vana, M., Dal Maso, M., Hussein, T., and Kulmala, M.: Aerosol particle formation events and analysis of high growth rates observed above a subarctic wetland-forest mosaic, Tellus, 60, 353-365, doi:10.1111/j.1600-0889.2008.00351.x, 2008.

Vanhanen, J., Mikkila, J., Lehtipalo, K., Sipila, M., Manninen, H. E., Siivola, E., Petaja, T., and Kulmala, M.: Particle Size Magnifier for Nano-CN Detection, Aerosol Sci. Tech., 45, 533-542, doi:10.1080/02786826.2010.547889, 2011.

von der Weiden, S.-L., Drewnick, F., and Borrmann, S.: Particle Loss Calculator - a new software tool for the assessment of the performance of aerosol inlet systems, Atmos. Meas. Tech., 2, 479-494, doi:10.5194/amt-2-479-2009, 2009.

Wang, J. and Wexler, A. S.: Adsorption of organic molecules may explain growth of newly nucleated clusters and new particle formation, Geophys. Res. Lett., 11, 2834-2838, doi:10.1002/grl.50455, 2013.
Wang, J., McGraw, R. L., and Kuang, C.: Growth of atmospheric nano-particles by heterogeneous nucleation of organic vapor, Atmos. Chem. Phys., 13, 6523-6531, doi:10.5194/acp-13-65232013, 2013.

Wiedensohler, A., Cheng, Y. F., Nowak, A., Wehner, B., Achtert, P., Berghof, M., Birmili, W., Wu, Z. J., Hu, M., Zhu, T., Takegawa, N., Kita, K., Kondo, Y., Lou, S. R., Hofzumahaus, A., Holland, F., Wahner, A., Gunthe, S. S., Rose, D., Su, H., and Pöschl, U.: Rapid aerosol particle growth and increase of cloud condensation nucleus activity by secondary aerosol formation and condensation: A case study for regional air pollution in northeastern China, J. Geophys. Res., 114, D00G08, doi:10.1029/2008jd010884, 2009.

Xiao, S., Wang, M. Y., Yao, L., Kulmala, M., Zhou, B., Yang, X., Chen, J. M., Wang, D. F., Fu, Q. Y., Worsnop, D. R., and Wang, L.: Strong atmospheric new particle formation in winter in urban Shanghai, China, Atmos. Chem. Phys., 15, 1769-1781, doi:10.5194/acp-15-1769-2015, 2015.

Yu, F. and Luo, G.: Simulation of particle size distribution with a global aerosol model: contribution of nucleation to aerosol and CCN number concentrations, Atmos. Chem. Phys., 9, 76917710, doi:10.5194/acp-9-7691-2009, 2009.

Yu, H., Gannet Hallar, A., You, Y., Sedlacek, A., Springston, S., Kanawade, V. P., Lee, Y. N., Wang, J., Kuang, C., McGraw, R. L., McCubbin, I., Mikkila, J., and Lee, S. H.: Sub-3 nm particles observed at the coastal and continental sites in the United States, J. Geophys. Res., 119, 860-879, doi:10.1002/2013jd020841, 2014a.

Yu, H., Ortega, J., Smith, J. N., Guenther, A. B., Kanawade, V. P., You, Y., Liu, Y., Hosman, K., Karl, T., Seco, R., Geron, C., Pallardy, S. G., Gu, L., Mikkilä, J., and Lee, S. H.: New Particle Formation and Growth in an Isoprene-Dominated Ozark Forest: From Sub-5 nm to CCN-Active Sizes, Aerosol Sci. Tech., 48, 1285-1298, doi:10.1080/02786826.2014.984801, 2014b.

Yue, D. L., Hu, M., Zhang, R. Y., Wu, Z. J., Su, H., Wang, Z. B., Peng, J. F., He, L. Y., Huang, X. F., Gong, Y. G., and Wiedensohler, A.: Potential contribution of new particle formation to cloud condensation nuclei in Beijing, Atmos. Environ., 45, 6070-6077, doi:10.1016/j.atmosenv.2011.07.037, 2011.

Zhang, K. M. and Wexler, A. S.: A hypothesis for growth of fresh atmospheric nuclei, J. Geophys. Res., 107, 4577, doi:10.1029/2002JD002180, 2002.

Zhao, J., Eisele, F. L., Titcombe, M., Kuang, C., and McMurry, P. H.: Chemical ionization mass spectrometric measurements of atmospheric neutral clusters using the cluster-CIMS, J. Geophys. Res., 115, D08205, doi:10.1029/2009JD012606, 2010. 